\title{
INCLUSION AND TRACE ELEMENT ChARACTERISTICS OF EMERALDS FROM Swat Valley, Pakistan
}

Hongshu Guo, Xiaoyan Yu, Yuyu Zheng, Zhulin Sun, and Miro Fei-Yeung Ng

Swat Valley has become an important source of emeralds, including recently discovered trapiche-type crystals. In this study, emerald samples from Swat were examined by standard gemological testing, UV-Vis-NIR, FTIR, Raman analysis, EDXRF, and LA-ICP-MS. The study found three-phase hexagonal inclusions consisting of water, gaseous carbon dioxide and nitrogen, and a magnesite crystal. The gaseous mixture in two-phase inclusions is characteristic in both trapiche-type $\left(\mathrm{CO}_{2}+\mathrm{N}_{2}\right)$ and non-trapiche samples $\left(\mathrm{CO}_{2}+\mathrm{N}_{2}+\mathrm{CH}_{4}\right)$. Mineral inclusions of hematite, magnetite, rutile, graphite, and siderite are reported for the first time. Regular non-trapiche-type Swat emeralds contain high chromium (avg. 7471 ppmw), alkali metal (avg. 21040 ppmw), magnesium (avg. 34263 ppmw), and iron (avg. 9265 ppmw), as well as scandium (avg. 633 ppmw). Infrared spectra show that the absorption of type II $\mathrm{H}_{2} \mathrm{O}$ is stronger than that of type $\mathrm{I} \mathrm{H}_{2} \mathrm{O}$. Logarithm plots of trace elements appear to be diagnostic. Based on Raman spectroscopy, the trapiche-type emeralds' colorless core, light green hexagonal growth zone area, and green rim are emerald, while the six black arms are a mixture of hematite and graphite.

$\mathrm{P}$ akistan's production of emeralds has been increasing in recent years, and reserves are estimated at almost 70 million carats (Jamal-ud-Din, 2014; Makki and Ali, 2019). Swat Valley is known for small stones with saturated color (figure 1). Mineralogical curiosities include three-phase fluid inclusions (Gübelin, 1982) and newly discovered trapiche-type emeralds (Khan, 2018). Photomicrographs of three-phase inclusions in Swat emeralds are provided for the first time in this study.

The history and geology of the Swat deposit were comprehensively reported by Arif et al. (2011) and Giuliani et al. (2019) and are summarized here. However, a detailed study of the inclusions and trace elements of Swat emeralds has not been published despite analytical and geological advances (Bowersox and Anwar, 1989; Gao et al., 2019).

Therefore, we present results from a detailed study of gemological properties, inclusions, spectroscopy, and chemical composition to characterize

See end of article for About the Authors and Acknowledgments.

Gems \& Gemology, Vol. 56, No. 3, pp. 336-355,

http://dx.doi.org/10.5741/GEMS.56.3.336

(C) 2020 Gemological Institute of America the emeralds from Swat Valley. Our findings provide insights that can be used for understanding the gen-

\section{In Brief}

- Emerald rough from Swat Valley in Pakistan shows a rather bright green color for melee. The rough is typically small and contains high $\mathrm{Cr}$ and $\mathrm{Fe}$ and low $\mathrm{V}$ contents. Relatively high-alkali metal (especially Li), Mg, $\mathrm{Fe}$, and Sc contents separate them from other sources.

- Colorless solid minerals such as magnesite, quartz, talc, and dolomite, as well as black graphite, are common in regular non-trapiche-type Swat emeralds and surrounding rocks.

- Three-phase inclusions are rare and hexagonal. Trapichetype emeralds from Swat Valley contain water, gaseous carbon dioxide and nitrogen, and a magnesite crystal.

- Trapiche-type emeralds from Swat Valley generally have four parts: one or two colorless cores, six arms or two sets of six arms (hematite + graphite), a light green area, and a green rim; these show a low-to-high content trend of $\mathrm{Fe}, \mathrm{Cr}$, Sc, and V.

esis of the emeralds in this deposit while shedding light on the geographic origin determination of emerald. 


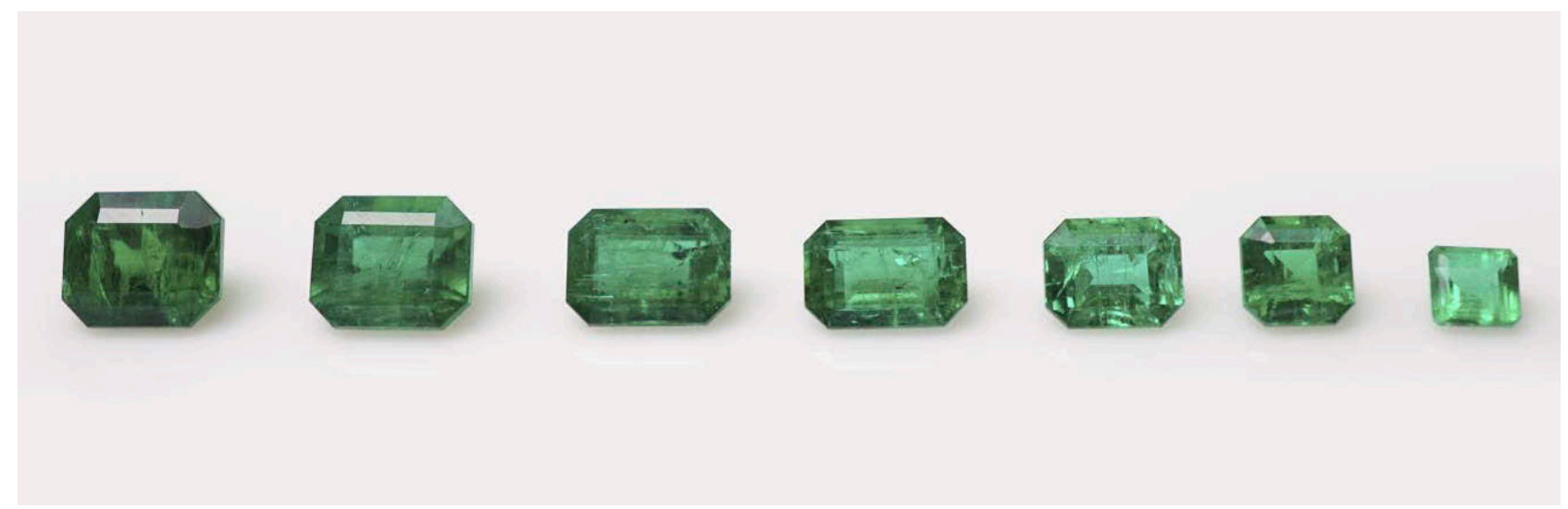

Figure 1. Swat emeralds are internationally renowned for their bright colors, even in small stones such as these, ranging from 0.3 to $0.8 \mathrm{ct}$. Photo by Hongshu Guo.

\section{HISTORY AND GEOLOGY}

Pakistan's emeralds have been found in four deposits, including Swat Valley in Swat District, Gandao in Mohmand Agency, Barang in Bajaur Agency, and Khaltaro in Gilgit-Baltistan (Khan, 2018). The Swat deposit is the largest of the four. The emerald mining area of Swat Valley is in northern Khyber Pakhtunkhwa and enclosed by the northwestern end of the Himalayan mountain range. To date, there are five mines in Swat Valley: Shamozai, Mingora, Gujar Killi, Charbagh, and Makhad (figure 2).
Mingora, Pakistan's earliest emerald mine, was discovered in 1958 (Khan, 2018). Initially, the Mingora, Gujar Killi, Charbagh, and Makhad mines in Swat Valley (figure 3) were explored, mined, and regulated by a state-owned company, Gemstone Corporation of Pakistan (GEMCP). From the early 1970s to the present, these four mines and the Shamozai mine have been taken over by different private companies. In 1981, Swat emeralds made their first appearance in the world market at the Tucson Gem and Mineral Show (Kazmi et al., 1986). Gübelin

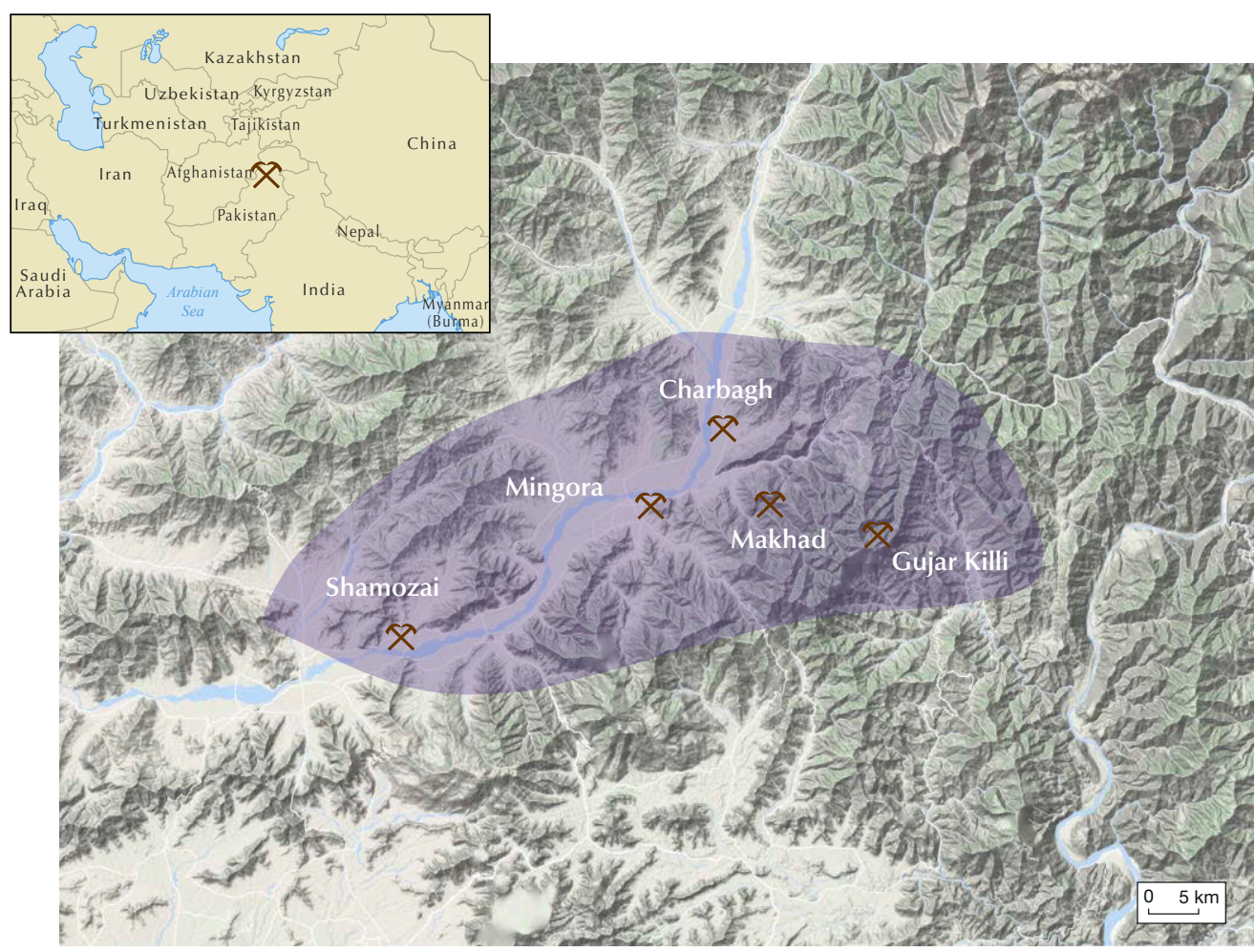

Figure 2. The Swat emerald deposit has five major mines. Gujar Killi is the most important source of highquality emeralds, followed by Mingora. 

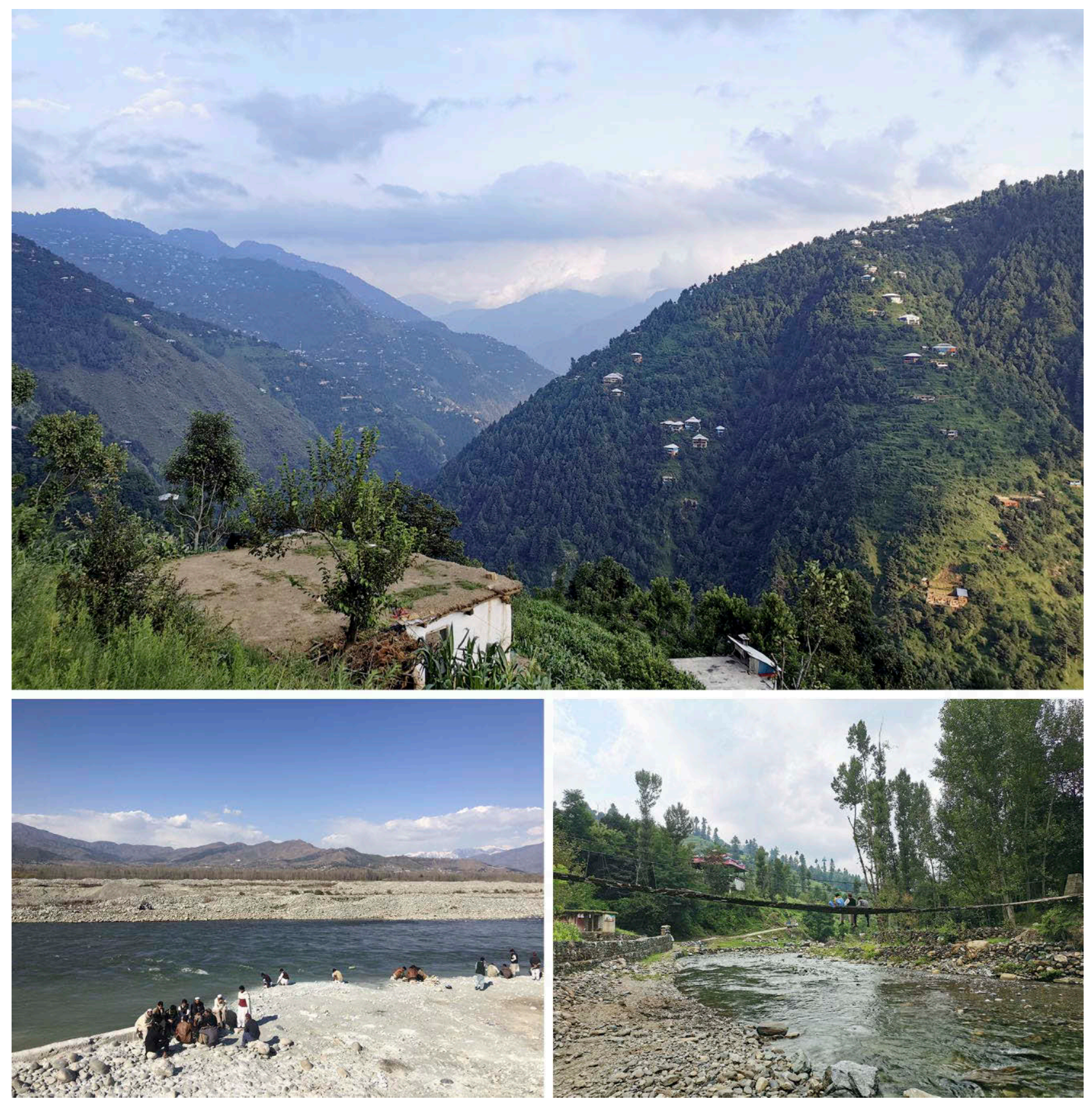

Figure 3. En route to mining areas along the ridge of Shangla Peaks (top) and the Swat River (bottom) in the Swat Valley are beautiful villages and terrain. The miners are panning emeralds by the Swat River. Photos courtesy of Cloud Walker Jewel, Inc.

(1982) first described the gemology of the Swat emeralds and their commercial value. At present, the Barang deposit and the Gujar Killi and Mingora mines in the Swat Valley deposit are the main producers of Pakistani emeralds.

The Swat Valley deposit occurs in the Indus suture zone mélange (Arif et al., 2011; Rehman et al., 2011). The Indus suture zone, extending eastward to the
Yarlung Zangbo suture zone in Tibet, represents fragments of the Neo-Tethyan upper mantle and the oceanic crust, which were emplaced on the continental margin and separate the Kohistan Arc sequence and the Eurasian plate to the north from the Indo-Pakistan plate to the south (Xu et al., 2015). In the Kohistan region, the Indus suture zone comprises Shangla blueschist mélange, the Charbagh greenschist 

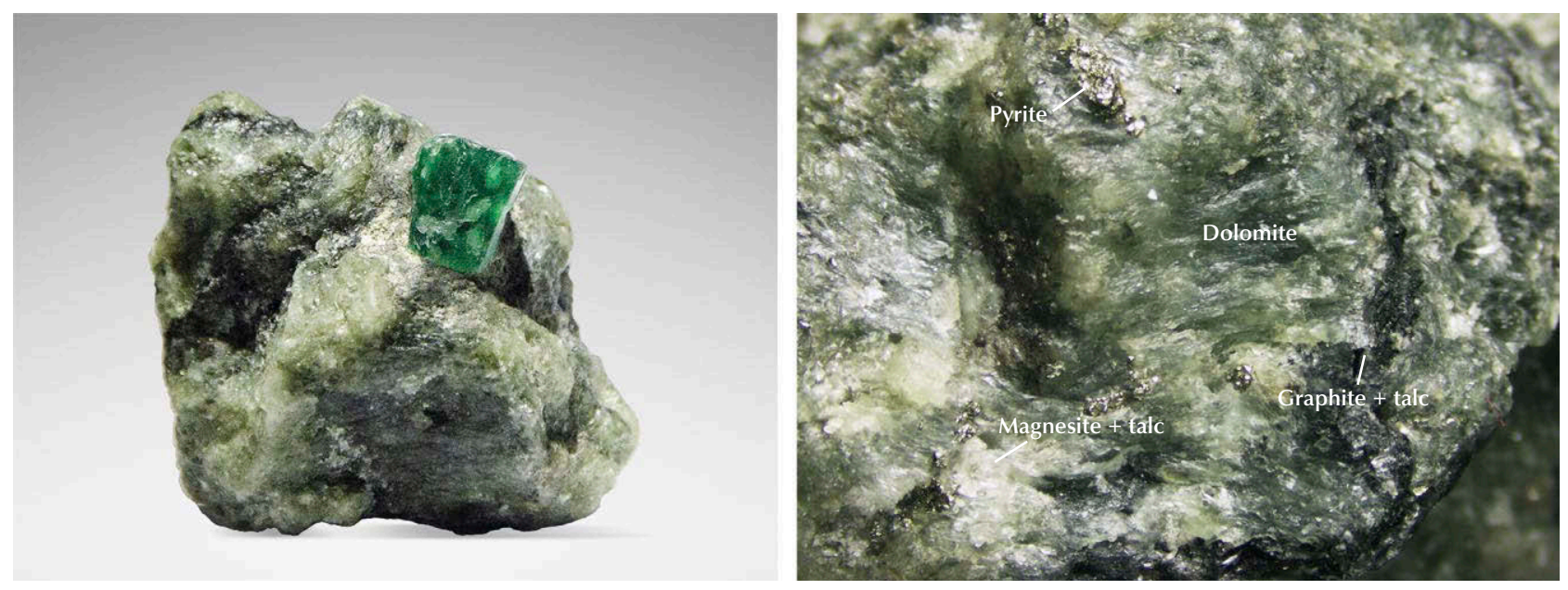

Figure 4. An emerald crystal specimen in matrix from the Mingora mine in Swat Valley. The emerald crystal measures about $7 \times 7 \times 8 \mathrm{~mm}$ (left). The matrix (right) mainly consists of dolomite (light green), magnesite + talc (white), graphite + talc (grayish black), and pyrite (pale brass-yellow), identified by Raman analysis. Photos by Hongshu Guo (left) and Xiaoyan Yu (right).

mélange, and the Mingora ophiolitic mélange (Arif et al., 2011). The ophiolitic rocks occur as lens-shaped bodies of various sizes distributed along the Main Mantle Thrust and are well exposed in the BarkotkaiLilaunai area, the Gujar Killi village, the Spin OboKuh area, and the town of Mingora.

Emerald deposits in Swat Valley are exposed in carbonate-magnesite-talc-altered ultramafic rocks, which also host high-Cr magnesian tourmaline (Giuliani et al., 2019). These emeralds formed during the Cenozoic era (23 Ma) (Dilles et al., 1994) and exist in magnesite-rich rocks (magnesite \pm talc \pm quartz \pm dolomite), as part of the Indus suture zone mélange, distributed mostly along contacts of serpentinized ultramafic rocks with carbonate \pm graphite-bearing metasedimentary rocks (Arif et al., 2011). Additionally, Groat et al. (2008) suggested that carbonate-altered ultramafic rocks hosting high-Cr magnesian tourmaline may be indicator minerals for emerald exploration.

Figure 4 shows an emerald crystal (about $7 \times 7 \times$ $8 \mathrm{~mm}$ ) in matrix from the Mingora mine in the Swat deposit. The matrix is composed mainly of light green dolomite, white magnesite + talc, grayish black graphite + talc, and pale brass-yellow pyrite, suggesting that this Swat emerald occurs in contact with serpentinized ultramafic rocks.

Chromium originates from the dissolution of chromite crystals in the serpentinites, and beryllium and boron from a leucogranite that may be hidden at depth (Lawrence et al., 1989; Arif et al., 1996,
2011). However, the source of vanadium remains uncertain.

Trapiche-type emeralds, containing a green rim, light green areas, six magnetite arms extending perpendicular to the outer crystal faces, and a colorless core (Gao et al., 2019), were found in the Fizzaghat mine near Mingora (Khan, 2018). However, the chemical composition and spectroscopy were not studied further. For more on trapiche-type emeralds from Swat Valley, see Schmetzer (2020), p. 438 of this issue.

By interviewing mine owners, we gained mineto-market information on Swat emerald. The emeralds are mined by traditional tunneling techniques. There are 30 active tunnels in the Mingora mine at about $1400 \mathrm{~m}$ elevation. Most have electricity but no ventilation. These tunnels were dug in a horizontal or slightly downward direction and were reported to be tens of meters to more than one kilometer long (figure 5, top and bottom left). The miners collect the emeralds using hydraulic jackhammers and handpicks along the white quartz vein (figure 5, bottom right). Mild winters, even in the snow, allow for continual mining though production may be reduced.

Emerald trading in Pakistan is traditional, without the use of the internet. Most transactions consist of local brokers buying rough stones from the mine owners, but there are also some foreign buyers. Some Swat emeralds are sold to the Indian and Bangkok markets, while other top-quality emeralds are sold to the Euro- 


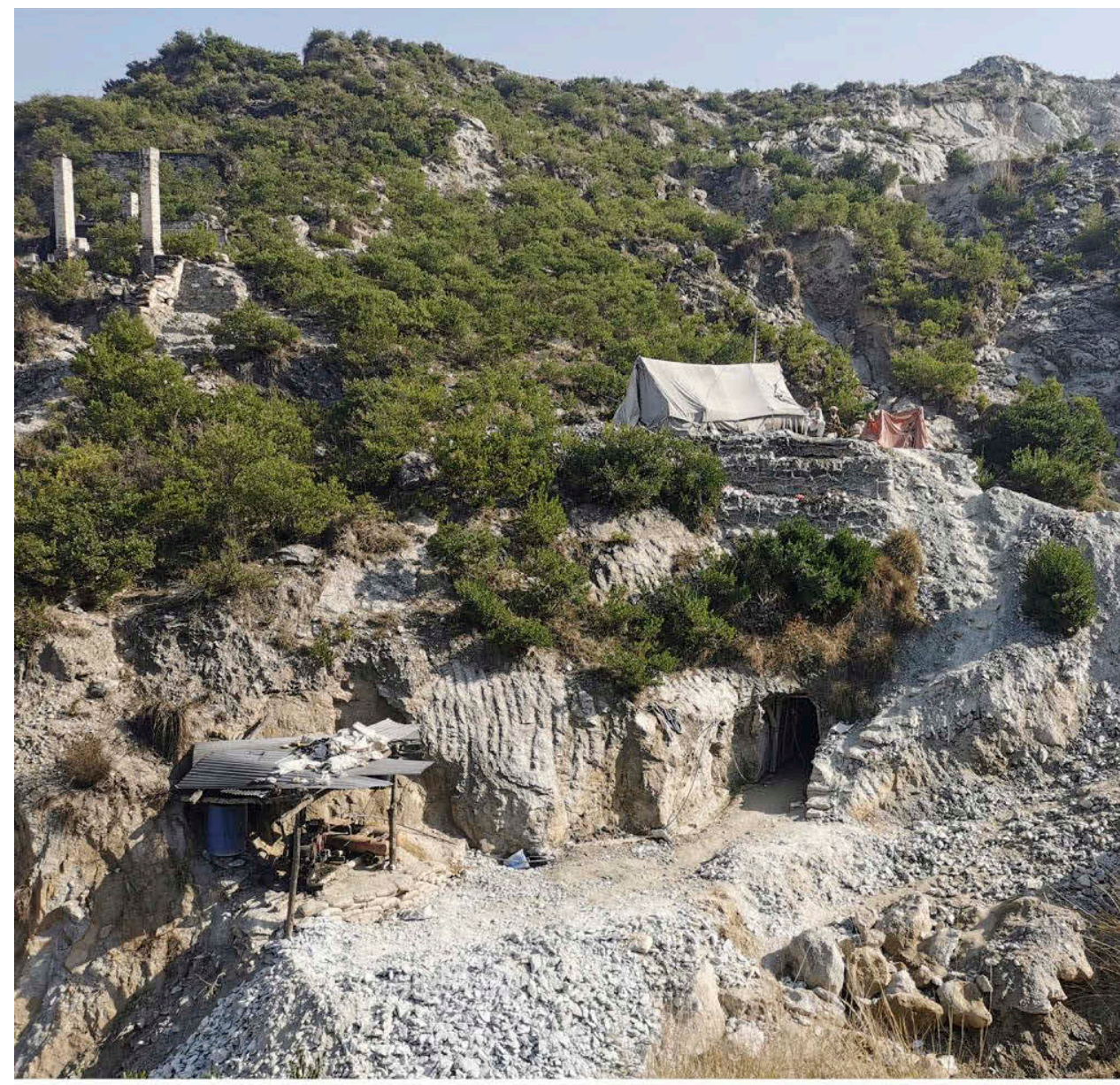

Figure 5. Top: The Mingora mine now has 30 active tunnels. Bottom left: The tunnels are dug in horizontal and slightly downward directions. Bottom right: The miners collect emeralds with hydraulic jackhammers and handpicks. Photos courtesy of Cloud
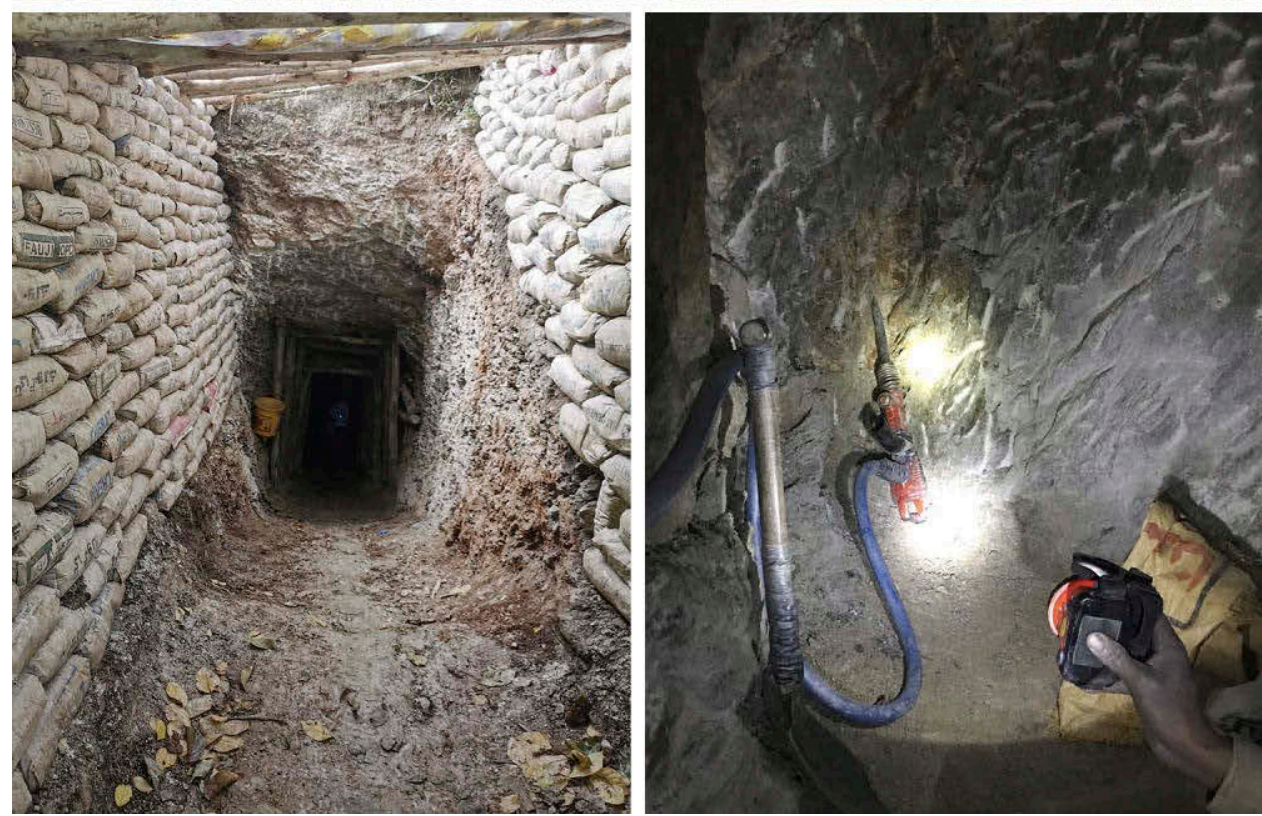

Walker Jewel, Inc.

pean and Middle Eastern markets. Swat emerald rough can range in price from a few dollars to thousands of dollars per carat.
In the international market, Swat emeralds have been favored by many jewelry and luxury watch brands. However, Swat emeralds have only become 


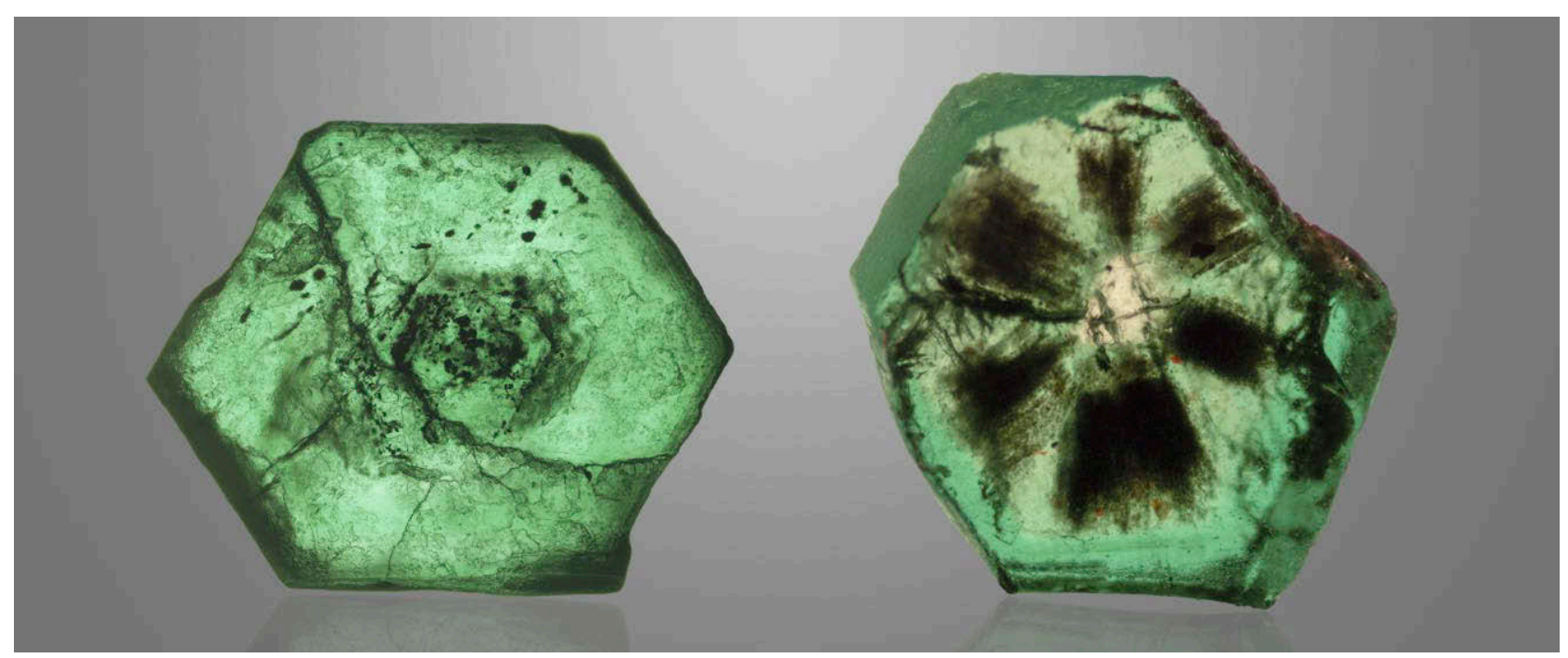

Figure 6. Double-sided emerald wafers from Swat Valley (about $5 \mathrm{~mm}$ in diameter) show the original hexagonal crystal habit and a trapiche-type pattern. Photo by Xiaoyan Yu.

widely known in the Chinese market in recent years and Swat is still considered a niche origin. More and more Chinese merchants go to Swat, Peshawar, and Islamabad in Pakistan to buy rough stones from local brokers for processing in China.

\section{MATERIALS AND METHODS}

A total of 37 regular emeralds and 16 trapiche-type emeralds from Swat Valley, ranging from 0.06 to 2.88 ct, were analyzed for the study: 26 were double-sided wafers or rough crystals with polished windows; 16 were hexagonal trapiche-type crystals fashioned as double-sided wafers (figure 6); and 11 were unfinished rough crystals. The "regular' or "non-trapiche-type" samples were selected from more than 700 rough emeralds weighing more than 550 ct (figure 7), obtained from a gem merchant in Swat Valley. The trapiche-type samples, ranging from 0.25 to $0.85 \mathrm{ct}$ with a size of 4 to $5 \mathrm{~mm}$, were provided by Miro FeiYeung Ng. The analytical results of regular Swat emeralds and trapiche-type emeralds are presented separately.

Standard gemological properties of all the samples were determined with a refractometer, a Chelsea filter, long-wave $(365 \mathrm{~nm})$ and short-wave $(254 \mathrm{~nm}) \mathrm{UV}$ lamps, and an apparatus for hydrostatic specific gravity testing.

Internal features were observed with a binocular gemological microscope and an Olympus polarizing

Figure 7. The 37 Swat emerald specimens for this study were selected from 700 rough stones that ranged from 3 to $15 \mathrm{~mm}$ and 0.05 to $17.0 \mathrm{ct}$. Photos by Xiaoyan Yu.
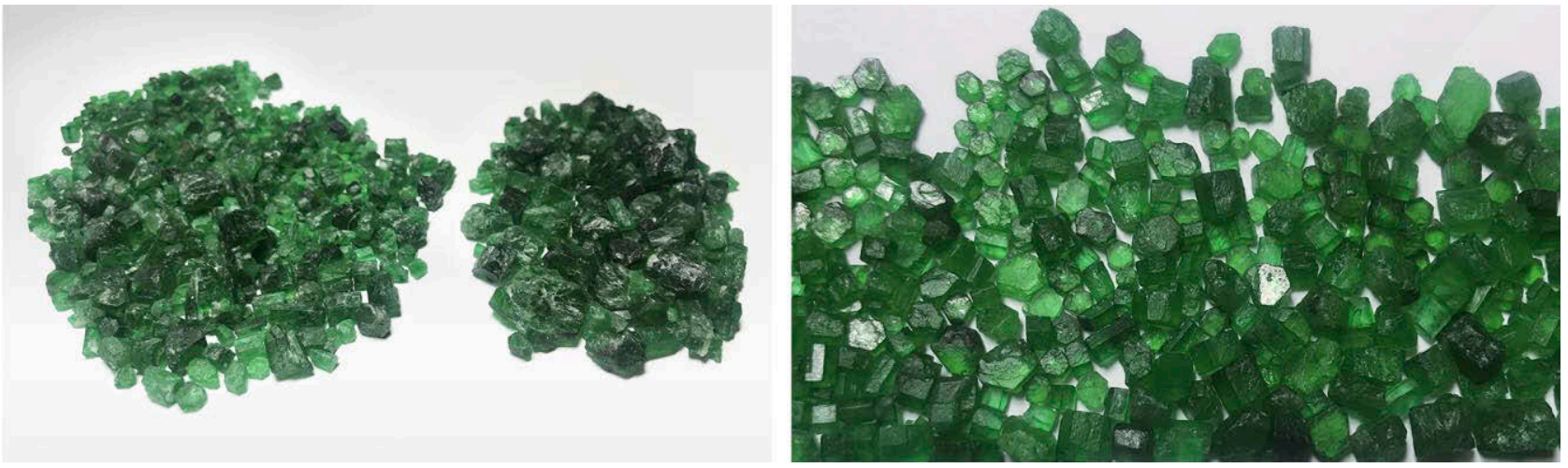
TABLE 1. Gemological properties of regular emeralds from Swat Valley, Pakistan. ${ }^{\text {a }}$

\begin{tabular}{|c|c|}
\hline Color & $\begin{array}{l}\text { Light to medium-dark slightly bluish green; typically a saturated green with a dark } \\
\text { tone }\end{array}$ \\
\hline Clarity & Very slightly to heavily included \\
\hline Refractive indices & $\begin{array}{l}\mathrm{n}_{\mathrm{o}}=1.587-1.600 ; \mathrm{n}_{\mathrm{e}}=1.580-1.589 \\
\mathrm{n}_{\mathrm{o}}=1.596 ; \mathrm{n}_{\mathrm{e}}=1.591^{\mathrm{b}} \\
\mathrm{n}_{\mathrm{o}}=1.599 ; \mathrm{n}_{\mathrm{e}}=1.589^{c}\end{array}$ \\
\hline Birefringence & $0.006-0.011\left(0.007^{\mathrm{b}}, 0.010^{\mathrm{c}}\right)$ \\
\hline Specific gravity & $2.70-2.82\left(2.78^{\mathrm{b}}, 2.72^{\mathrm{c}}\right)$ \\
\hline Pleochroism & Strong to medium yellowish green or green (o-ray) and bluish green (e-ray) \\
\hline Fluorescence & $\begin{array}{l}\text { Typically inert to long- and short-wave UV radiation; sometimes faint yellowish } \\
\text { green to long-wave UV }\end{array}$ \\
\hline Chelsea filter & Pink to red (stones with saturated colors) or no reaction \\
\hline Visible spectrum & $\begin{array}{l}\text { Distinct lines at } \sim 680 \mathrm{~nm} \text {; partial absorption between } 550 \text { and } 630 \mathrm{~nm} \text {; and } \\
\text { complete absorption }<460 \mathrm{~nm}\end{array}$ \\
\hline \multirow[t]{4}{*}{ Internal features } & $\begin{array}{l}\text { - Partially healed fissures with two-phase inclusions_-typically elongated, necked- } \\
\text { down, or irregular }\end{array}$ \\
\hline & $\begin{array}{l}\text { - Three-phase inclusions containing a gas bubble and a colorless crystal, usually } \\
\text { with a hexagon outline, are uncommon }\end{array}$ \\
\hline & $\begin{array}{l}\text { - Hexagonal color zoning or core partially occurs on planar zones oriented } \\
\text { perpendicular to the prism faces }\end{array}$ \\
\hline & $\begin{array}{l}\text { - Mineral inclusions: clusters of minute grains of magnesite and hematite; rounded } \\
\text { crystals of dolomite, quartz, and fluorite; blocks of siderite and talc; platelets of } \\
\text { muscovite and rutile }\end{array}$ \\
\hline \multicolumn{2}{|c|}{$\begin{array}{l}{ }^{2} \text { All data are from the present study unless otherwise noted. } \\
\text { 'Data from Gübelin (1982), given mean from } 70 \text { samples. } \\
\text { 'Data from Bowersox and Anwar (1989), obtained from eight faceted samples. }\end{array}$} \\
\hline
\end{tabular}

microscope objective using darkfield, brightfield, and fiber-optic illumination. Photomicrographs were captured with an Olympus DP2-TWAIN system at 10x to $400 \times$ magnification.

UV-Vis-NIR spectra were recorded on a QSPEC GEM-3000 spectrophotometer in the range of 200$950 \mathrm{~nm}$ with a $0.5 \mathrm{~nm}$ spectral resolution and 180$200 \mathrm{~ms}$ integral time. When possible, polarized spectra of oriented samples were collected for obtaining ordinary ray (o-ray) and extraordinary ray (e-ray) absorption spectra.

Infrared spectroscopy was performed by a Bruker Tensor 27 Fourier-transform infrared spectrometer (FTIR) in transmission mode and resolution set at 4 $\mathrm{cm}^{-1}$. The scanning ranges were $7200-2000 \mathrm{~cm}^{-1}$.

Inclusions were identified using a Horiba LabRAM HR-Evolution Raman spectrometer with an Ar-ion laser operating at $532 \mathrm{~nm}$ excitation, between 4000 and $100 \mathrm{~cm}^{-1}$, and accumulating up to two scans.

The elemental concentrations of trapiche-type emeralds were determined by the energy-dispersive $\mathrm{X}$ ray fluorescence (EDXRF) technique using a Shimadzu EDX-7000 (15-50 kV, $1000 \mu \mathrm{A}, 0-40$ acquisitions, atmospheric conditions, and $1 \mathrm{~mm}$ scanning cores).
Trace element chemistry was performed using a Thermo X-Series ICP-MS fitted with a $343 \mathrm{~nm}$ femtosecond laser ablation system (Applied Spectra J100), at the National Research Center for Geoanalysis, Chinese Academy of Geological Sciences (CAGS), Beijing. We used a laser repetition rate of $8 \mathrm{~Hz}$ at $8 \mathrm{~J} / \mathrm{cm}^{2}$ and spot diameters of $\sim 20 \mu \mathrm{m}$. A baffled smoothing device was used in front of the ICP-MS to reduce fluctuation effects induced by laser-ablation pulses and improve the quality of measurement data (Li et al., 2018). Each analysis consisted of $\sim 10$ seconds of background acquisition of gas blank measurement followed by 20 seconds of data acquisition from the sample. NIST SRM 610 and NIST SRM 612 were used as calibration reference materials for every 10 analyses to correct the time-dependent drift of sensitivity and mass discrimination. Data reduction was carried out with ICPMS Data Cal 10.8 software and specific analytical procedures and calibration methods (see Liu et al., 2008).

\section{RESULTS}

Gemological Properties. The gemological properties of regular emeralds from Swat Valley are summarized in table 1 and discussed in detail below. 


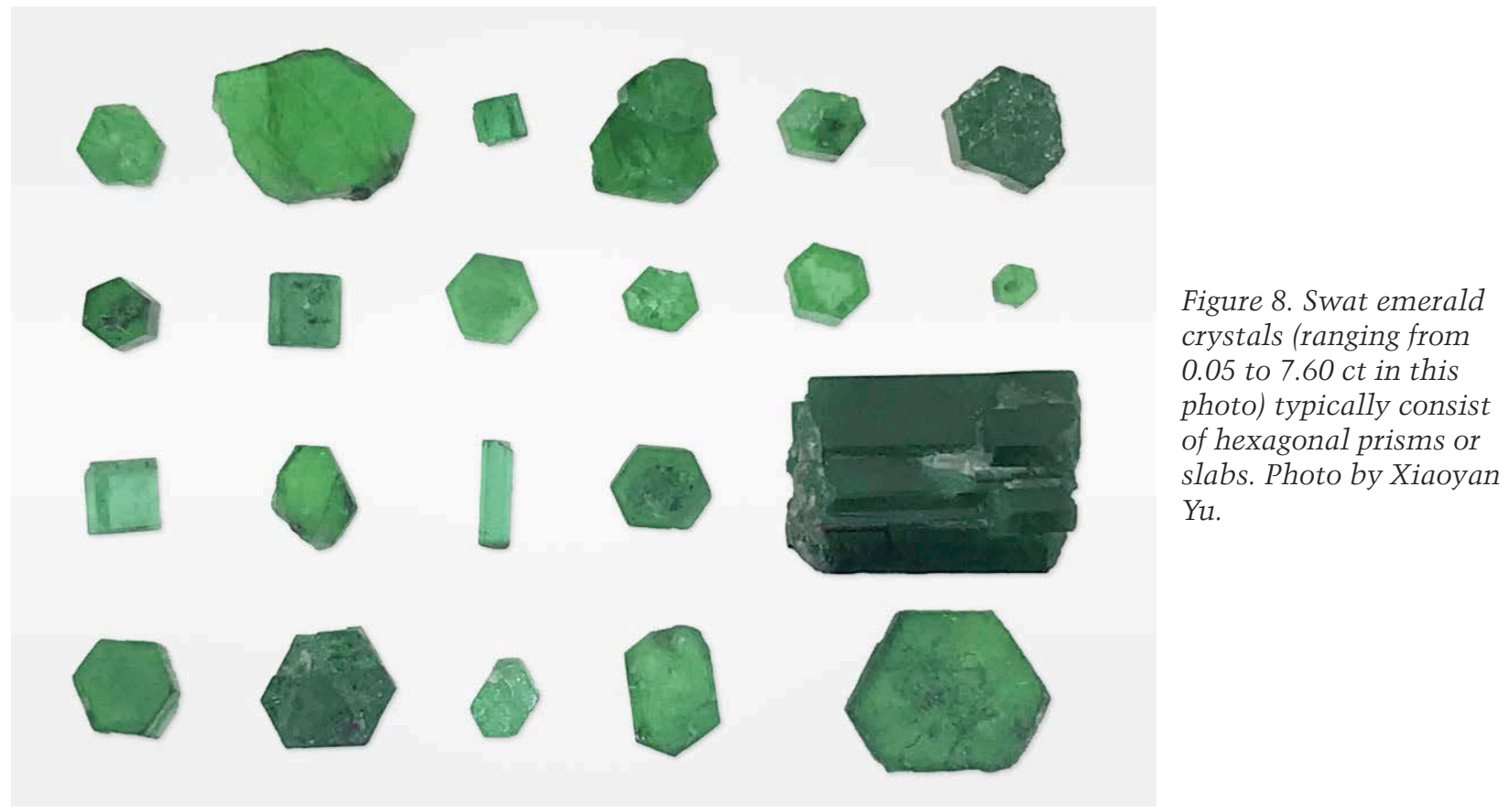

The rough emeralds from Swat Valley were typically small $(<1.00 \mathrm{ct})$, but some weighed over $15 \mathrm{ct}$. The rough appeared as prisms, slabs, or fragments. Well-formed crystals typically showed short hexagonal prisms or slabs (figure 8). The majority ranged from 3 to $15 \mathrm{~mm}$, but some were a few centimeters long. Larger crystals appeared to be translucent to opaque, whereas smaller crystals $(<4 \mathrm{~mm})$ were transparent. Polished regular emeralds typically showed a dark slightly bluish green color, and others were medium to light green. The color was evenly distributed, while moderate hexagonal color zones or cores were observed in the flat terminations.

Similarly, trapiche-type emeralds ranging from 0.25 ct to 0.85 ct showed an intense to vivid green color in our study. There were four parts from the core to rim: a colorless core, six arms, a light green hexagonal growth zone area, and a green rim, while some had two colorless hexagonal cores (figure 9). In one sample, a colorless core was divided into two parts, indicating that this trapiche-type emerald went through different growth periods (figure 10). The colorless core formed as a completely hexagonal crystal before the green rims and black arms formed.

The regular emeralds from Swat Valley had a refractive index of 1.580-1.600, with birefringence be-

Figure 9. The structure of the trapiche-type emeralds was observed in visible light. They displayed black arms (left and center, transmitted light) with metallic luster (right, reflected light), and the emerald host showed hexagonal symmetrical patterns. The left and right samples have a hexagonal core, a hexagonal growth zone, and six arms, respectively. The middle emerald has two cores and two sets of six arms. Photos by Xiaoyan Yu; field of view $6.0 \mathrm{~mm}$.
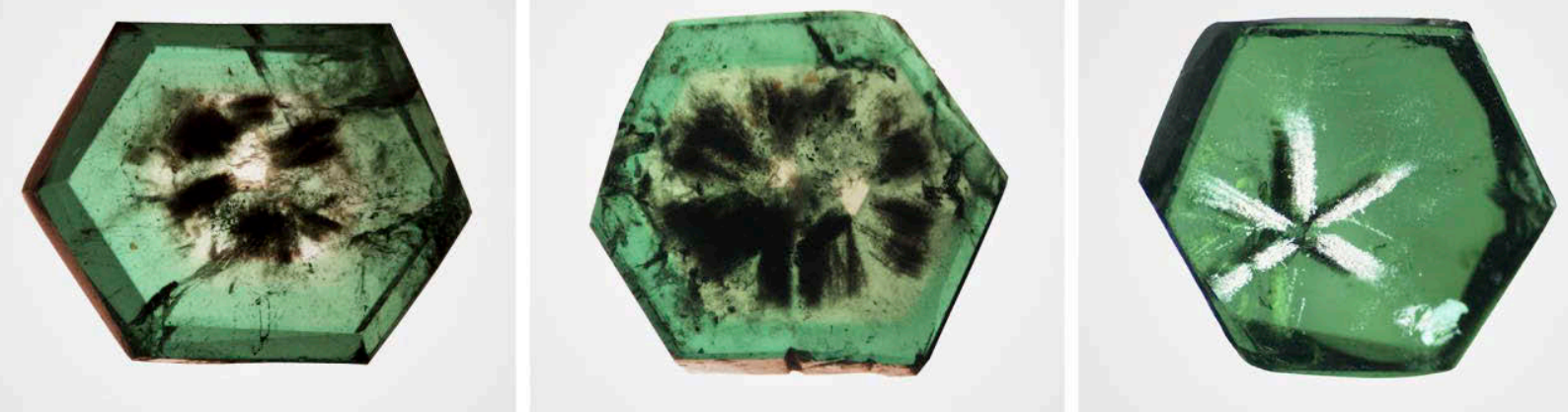


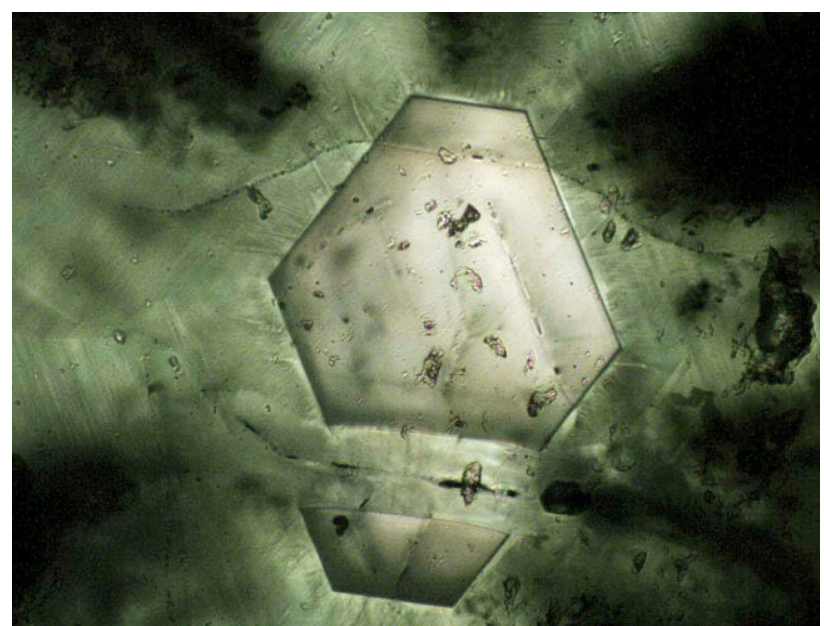

Figure 10. Separate parts in a hexagonal colorless core show multiple growth periods for a trapiche-type emerald. Photomicrograph by Hongshu Guo; field of view $0.6 \mathrm{~mm}$.

tween 0.006 and 0.011. Meanwhile, the trapiche-type emeralds had a refractive index of 1.589-1.601, with birefringence between 0.009 and 0.011 . Specific gravity varied from 2.70 to 2.82 , including the trapichetype emerald values of 2.74-2.77.

Pleochroism was strong to medium yellowish green or green (o-ray) and bluish green (e-ray). The regular emeralds were typically inert to long- and shortwave UV radiation, but some had faint yellowish green fluorescence under long-wave radiation. Through the Chelsea filter, the more saturated samples appeared pink to red, while the less saturated samples showed no response. The visible spectrum of most emeralds from the spectroscope had distinct lines at $\sim 680 \mathrm{~nm}$, partial absorption between 550 and $630 \mathrm{~nm}$, and complete absorption in the violet range (<460 nm). Small or light green emeralds showed a weaker spectrum, with two clear lines at about 650 and $680 \mathrm{~nm}$, and a weak band below $460 \mathrm{~nm}$.

Microscopic Characteristics. The most common inclusions in the regular Swat emeralds were partially
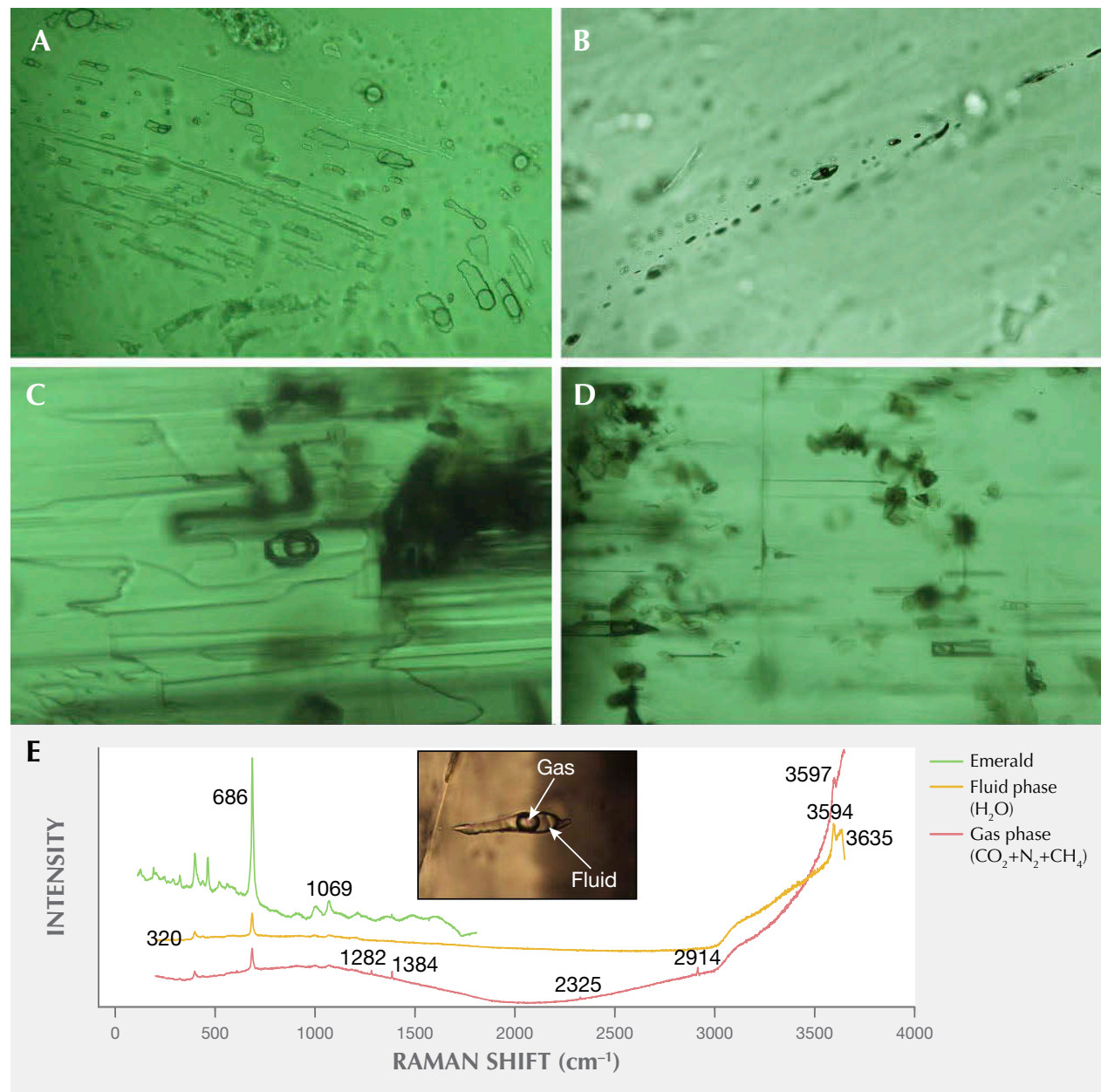

Figure 11. Multi-phase inclusions are commonly observed in regular Swat emeralds. They typically show necked-down, irregular, and elongated shapes (A and B). Two-phase inclusions with a negative crystal shape are rare in the regular emeralds (C). Two-phase primary inclusions oriented parallel to the $c$-axis and platelets of muscovite were commonly seen in thin and moderately green emeralds $(D)$. Raman spectroscopy (E) was used to identify the host emerald (green), the aqueous fluid phase (orange), and the $\mathrm{CO}_{2}+\mathrm{N}_{2}+\mathrm{CH}_{4}$ gas bubble (red). Photomicrographs by Hongshu Guo; fields of view $0.30,0.40,0.48,0.40$, and $0.12 \mathrm{~mm}$, respectively. 

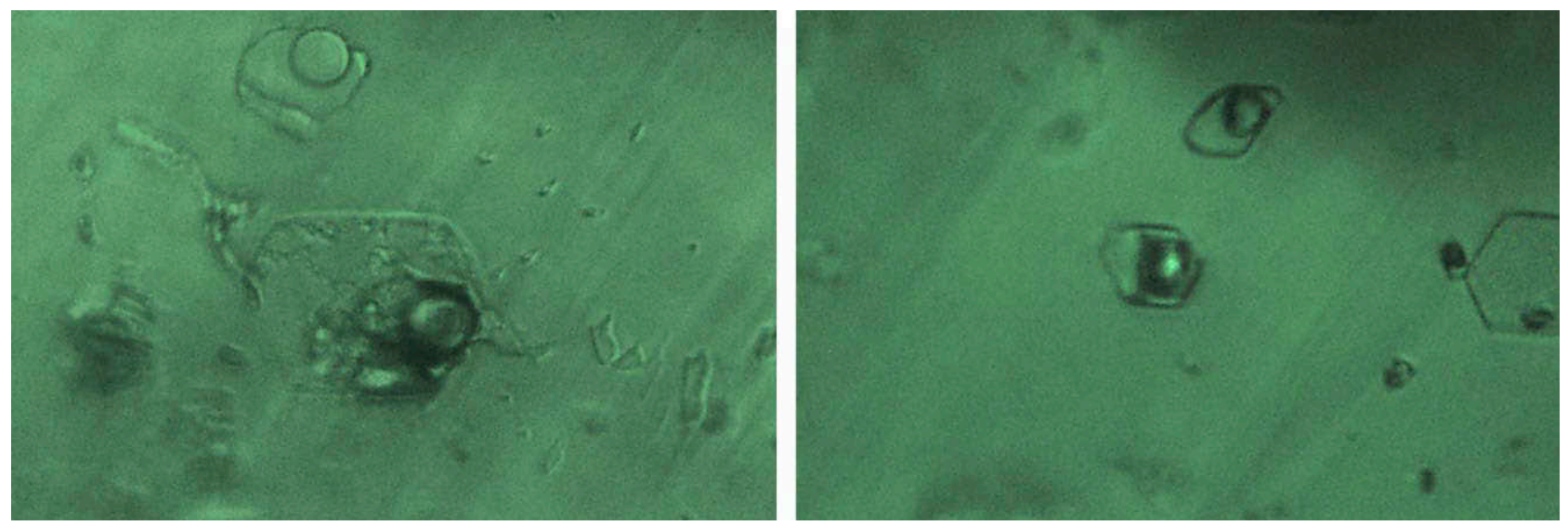

Figure 12. Three-phase inclusions showed a hexagonal outline in the regular Swat emeralds. Photomicrographs by Hongshu Guo; field of view $0.4 \mathrm{~mm}$.

healed fissures with two-phase inclusions. Twophase inclusions were typically elongated, neckeddown, or of irregular shape (figure 11, A and B) and contained a gas bubble $\left(\mathrm{CO}_{2}+\mathrm{N}_{2}+\mathrm{CH}_{4}\right.$, identified by Raman). At room temperature, the gaseous bubbles in the multi-phase fluid inclusions appeared to account for one-third to one-half of the volume of the multi-phase inclusion; sometimes they were even larger than the present irregular mineral inclusions. Unlike pseudo-secondary fluid inclusions commonly found in healed fissures, two-phase primary inclusions were rarely observed. The primary two-phase inclusions occurred as isolated negative crystals with an approximate hexagonal profile and high relief (figure 11C). Two-phase primary inclusions oriented parallel to the c-axis were commonly seen in thin emeralds with medium green color (figure 11D). Hexagonal three-phase inclusions were rare in the regular emeralds (figure 12). They contained a gas bubble and a crystal in an aqueous solu- tion, but the composition could not be identified by Raman analysis.

Solid inclusions were common in the regular Swat emeralds. Clusters of magnesite grains occurred in most of the emeralds. Rounded crystals of dolomite, quartz, and fluorite (figure 13, left) were found in some samples. Crystals of siderite and talc were generally found to be slightly rounded. Dark minerals included platelets of muscovite (figure 11D) and light to deep brown rutile (figure 13, center). Black magnetite and carbon inclusions were also visible on emerald surfaces and ridgelines (figure 13, right).

Trapiche-type emeralds from Swat Valley contained abundant two- and three-phase inclusions and solid inclusions. Three-phase inclusions were more common in the trapiche-type emeralds than in the regular Swat emeralds. In one sample, the solid was identified by Raman analysis as magnesite, indicating that multi-phase inclusions had captured sur-

Figure 13. Rounded colorless fluorite (left), brown rutile (center), and a mixture of black magnetite + graphite (right) were identified by Raman analysis in the regular Swat emeralds. Photomicrographs by Hongshu Guo; field of view 0.48, 0.48, and $2 \mathrm{~mm}$, respectively.
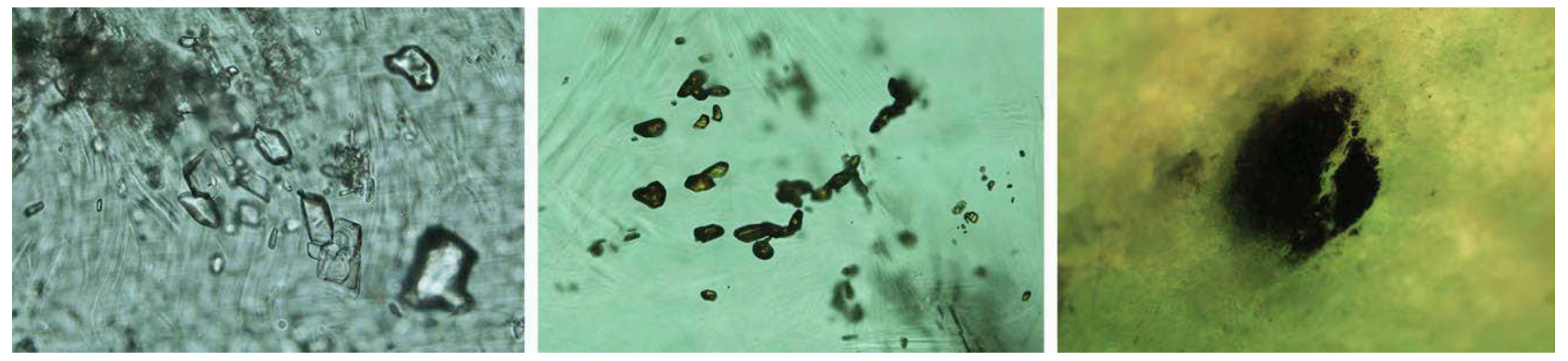
rounding minerals (figure 14). Gas mixtures of $\mathrm{CO}_{2}$ $+\mathrm{N}_{2}$ in two- and three-phase inclusions in trapichetype emeralds (identified by Raman analysis) were different from those in regular Swat emeralds.

The structural components and solid inclusions of the trapiche-type emeralds were identified by Raman analysis. The colorless core, light green area, and green rim were emerald. Meanwhile, the six black arms were a mixture of hematite and graphite. Hematite showed a skeleton-like pattern, with metallic luster and was opaque under reflected light (figure 15A). Trapiche-type emeralds containing only a colorless core and a green rim and no light green areas were observed (figure 15B). A series of black graphite needles were along the fracture direction (figure 15C), and colorless needles intersected vertically with short tubular multi-phase fluid inclusions in the colorless core (figure 15D). Brown minerals of hexagonal and triangular shape were identified as hematite (figure 15E). Irregular or triangular plates of brown rutile and colorless crystal inclusions (figure 15F) were observed in the trapiche-type emeralds.

Spectroscopy. UV-Vis-NIR. A representative UV-VisNIR e-ray spectrum of the regular Swat emeralds is shown in figure 16 (blue line). There are four characteristic absorption bands: wide bands at 425 and 600-680 nm, a strong band at $850 \mathrm{~nm}$, and a narrow band at $370 \mathrm{~nm}$. Compared to Wood and Nassau (1968) and Schmetzer et al. (1974), the most prominent features in this group were the $\mathrm{Cr}^{3+}$ bands at $425,610,637,660$, and $681 \mathrm{~nm}$. In addition, the narrow band at around $370 \mathrm{~nm}$ indicated the presence of $\mathrm{Fe}^{3+}$, and a strong $\mathrm{Fe}^{2+}$ band at $850 \mathrm{~nm}$ was recorded. But in some samples, a weak $\mathrm{Fe}^{2+}$ band was present at $830 \mathrm{~nm}$.

As figure 16 (red line) shows, the e-ray spectrum of Swat trapiche-type emerald is different from that of regular emeralds. A significant $\mathrm{Fe}^{3+}$ absorption band was observed at $370 \mathrm{~nm}$. The difference in Fe peaks may be attributed to the Fe-rich metallogenic fluid of trapiche-type emeralds. Moreover, significant $\mathrm{Cr}^{3+}$ bands at about 430, 610, 635, and $681 \mathrm{~nm}$ and the $\mathrm{Fe}^{2+}$ band at $850 \mathrm{~nm}$ were similar to those in regular emeralds.

UV-Vis-NIR spectroscopy shows differences between trapiche-type and regular emeralds. The chemistry in figure 18 agrees well with UV-Vis-NIR spectra. The concentrations of $\mathrm{Fe}$ in trapiche-type emeralds (17801 ppmw) are over four times as much as those in regular Swat emeralds (3825 ppmw).

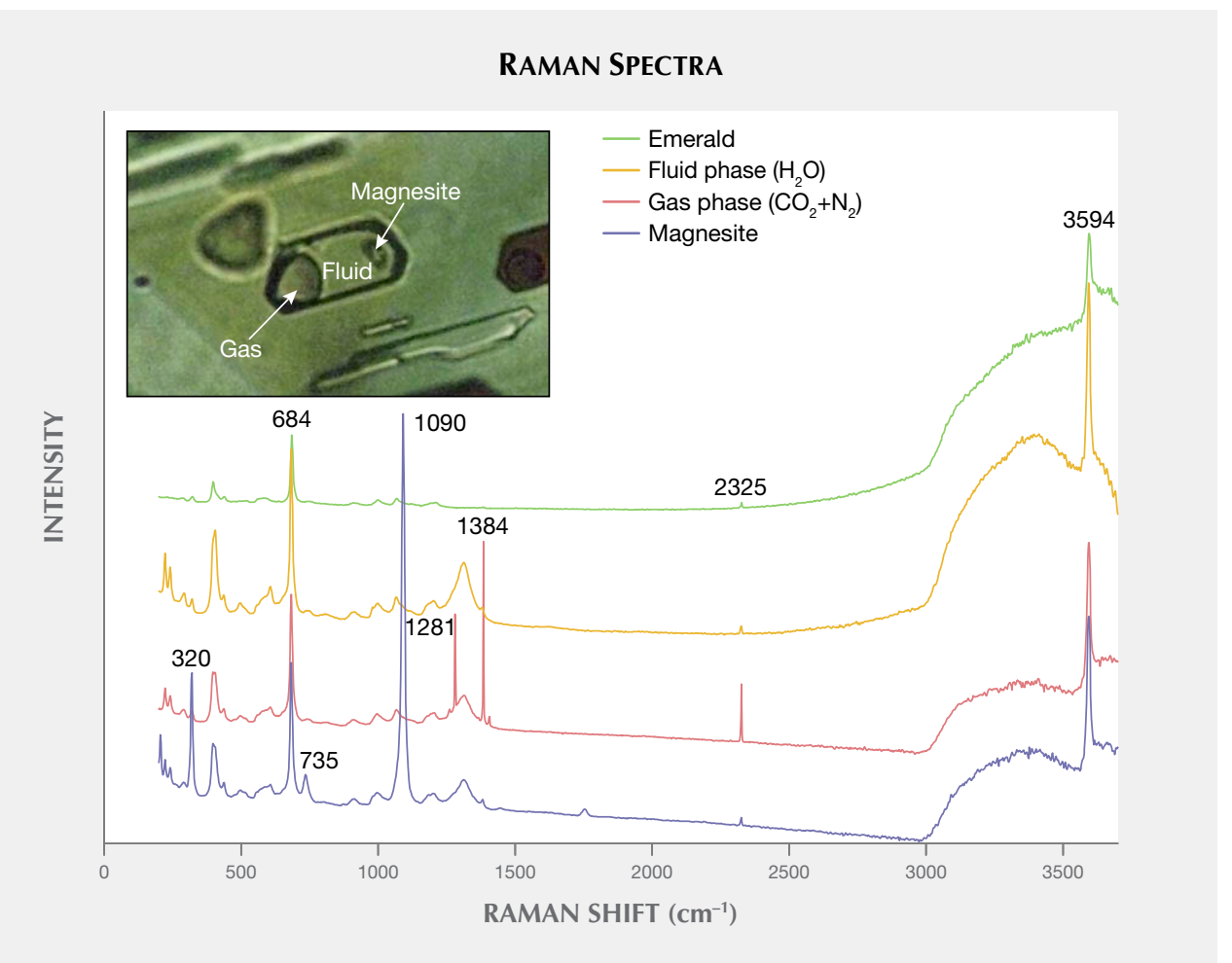

Figure 14. This hexagonal inclusion in Swat trapiche-type emerald clearly displays a gas bubble and a colorless crystal. Raman spectroscopy was used to identify the host emerald (green), the $\mathrm{CO}_{2}+$ $\mathrm{N}_{2}$ gas bubble (pink), the aqueous fluid phase (orange), and the magnesite crystal (blue). Photomicrograph by Hongshu Guo; field of view $0.08 \mathrm{~mm}$. The spectra are stacked for clarity. 

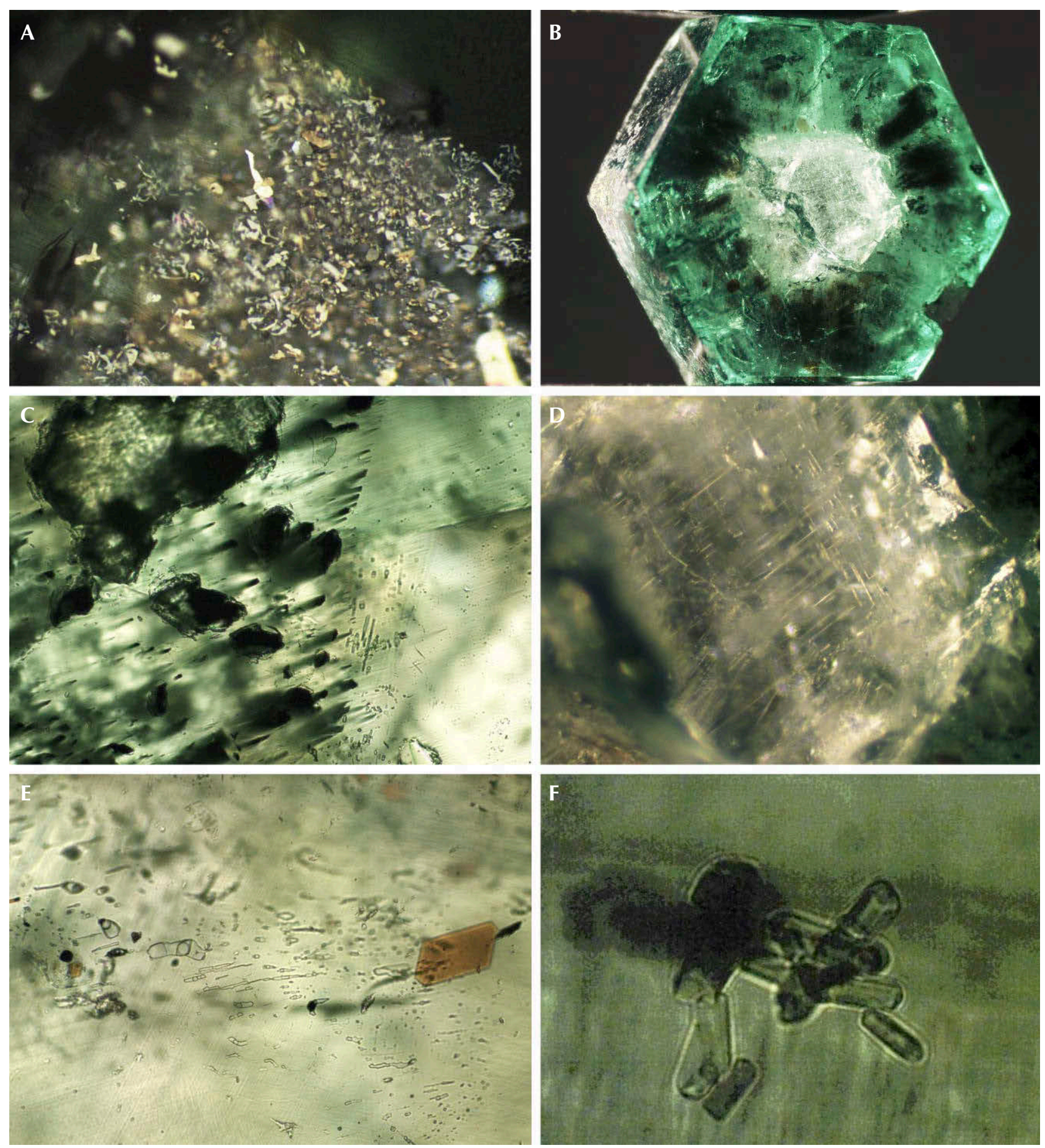

Figure 15. The six black arms in the trapiche-type emeralds were a mixture of hematite and graphite. Skeletonlike hematite arms showed bright metallic luster and were opaque under reflected light (A). A few trapichetype emeralds had no light green area, only colorless and green parts (B). A cluster of black graphite needles along the fracture (C). Colorless needle-shaped inclusions and short tubular multi-phase fluid inclusions were vertically crossed in the colorless core (D). The two-phase inclusion was composed of a mixture of $\mathrm{CO}_{2}+\mathrm{N}_{2}$ gas and liquid water. The brown hexagonal mineral was identified as hematite (E). A cluster of colorless crystal inclusions (F). Photomicrographs by Xiaoyan Yu (B, C, and D) and Hongshu Guo (A, E, and F); fields of view $0.7,5.0,0.6,2.2,0.7$, and $0.08 \mathrm{~mm}$, respectively. 


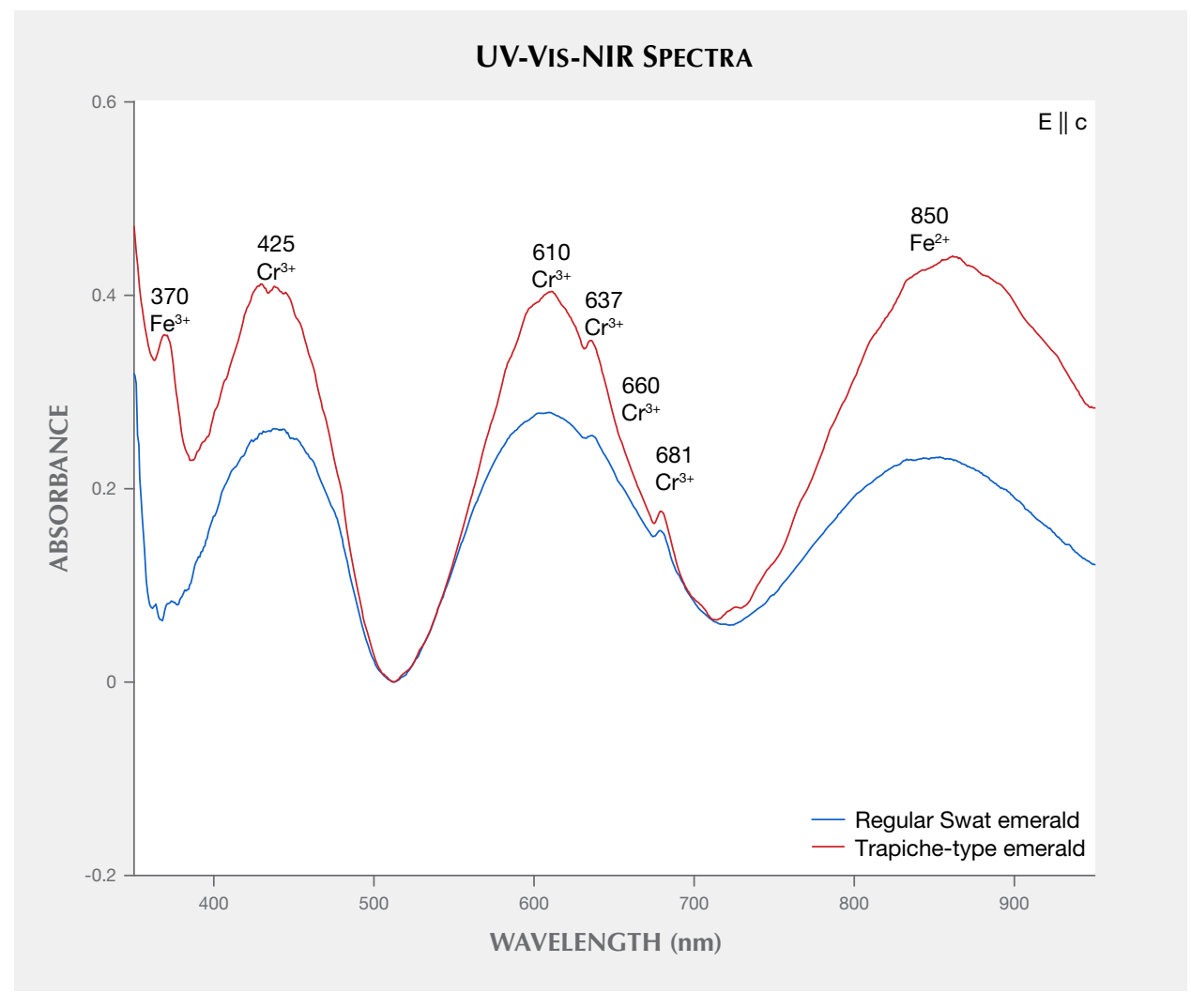

Figure 16. These UVVis-NIR absorption spectra are representative of regular Swat emeralds (blue line) and trapiche-type Swat emeralds (red line) in this study. Note: LAICP-MS and EDXRF analysis gave values corresponding to the different emeralds. Regular: 4618 ppmw $\mathrm{Cr}$, 764 ppmw $V$, and 3825 ppmw Fe. Trapichetype: $4789 \mathrm{ppmw} \mathrm{Cr}$, $272 \mathrm{ppmw} V$, and 18045 ppmw Fe.

Infrared. Figure 17 (left) shows typical FTIR spectra (eray) in the range of $7200-2000 \mathrm{~cm}^{-1}$. There is absorption of $\mathrm{H}_{2} \mathrm{O}$ in the channels of the emerald structure. The peaks at 7095 and $5267 \mathrm{~cm}^{-1}$ of type $\mathrm{II} \mathrm{H}_{2} \mathrm{O}$ are sharp and strong, while the peak at $6843 \mathrm{~cm}^{-1}$ of type
I is sharp but weak. According to Saeseaw et al. (2014), these three characteristic peaks of the Swat emeralds correspond to the vibration of type I and type $\mathrm{II}_{2} \mathrm{O}$ molecules. The significant peak at $2356 \mathrm{~cm}^{-1}$ corresponds to $\mathrm{CO}_{2}$, which was present in all the samples.

Figure 17. The representative FTIR spectrum (E $\| c)$ illustrating type I and type II $\mathrm{H}_{2} \mathrm{O}$ was observed in Swat emeralds (left). Peaks in the 3200-2500 $\mathrm{cm}^{-1}$ range were seen in some of the stones (right), suggesting a mixture of cedarwood oil and Araldite 6010.

FTIR SPECTRUM

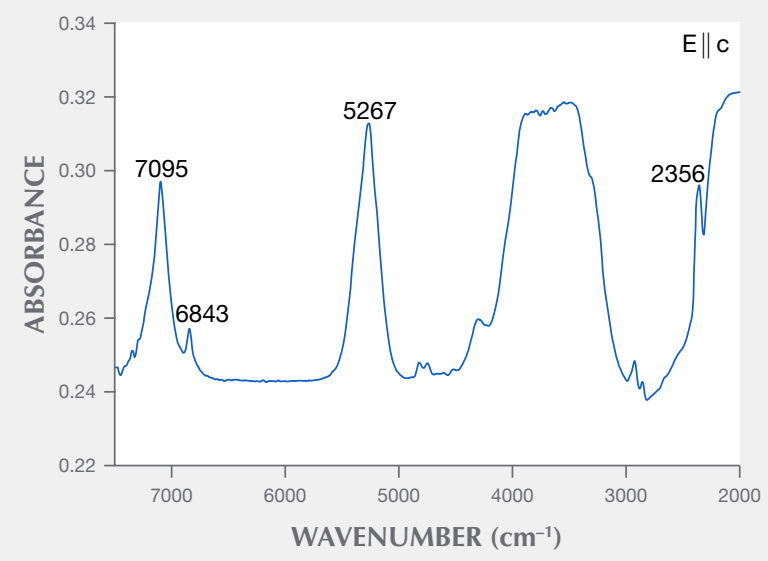

FTIR SPECTRUM

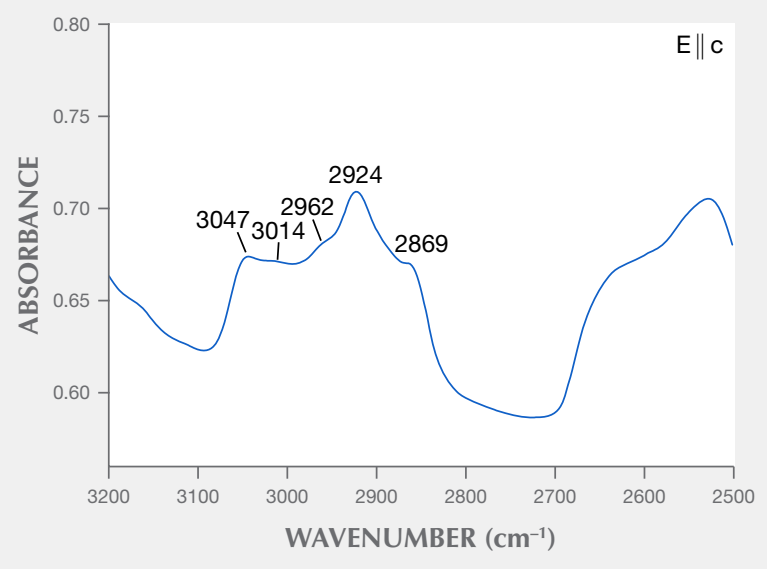




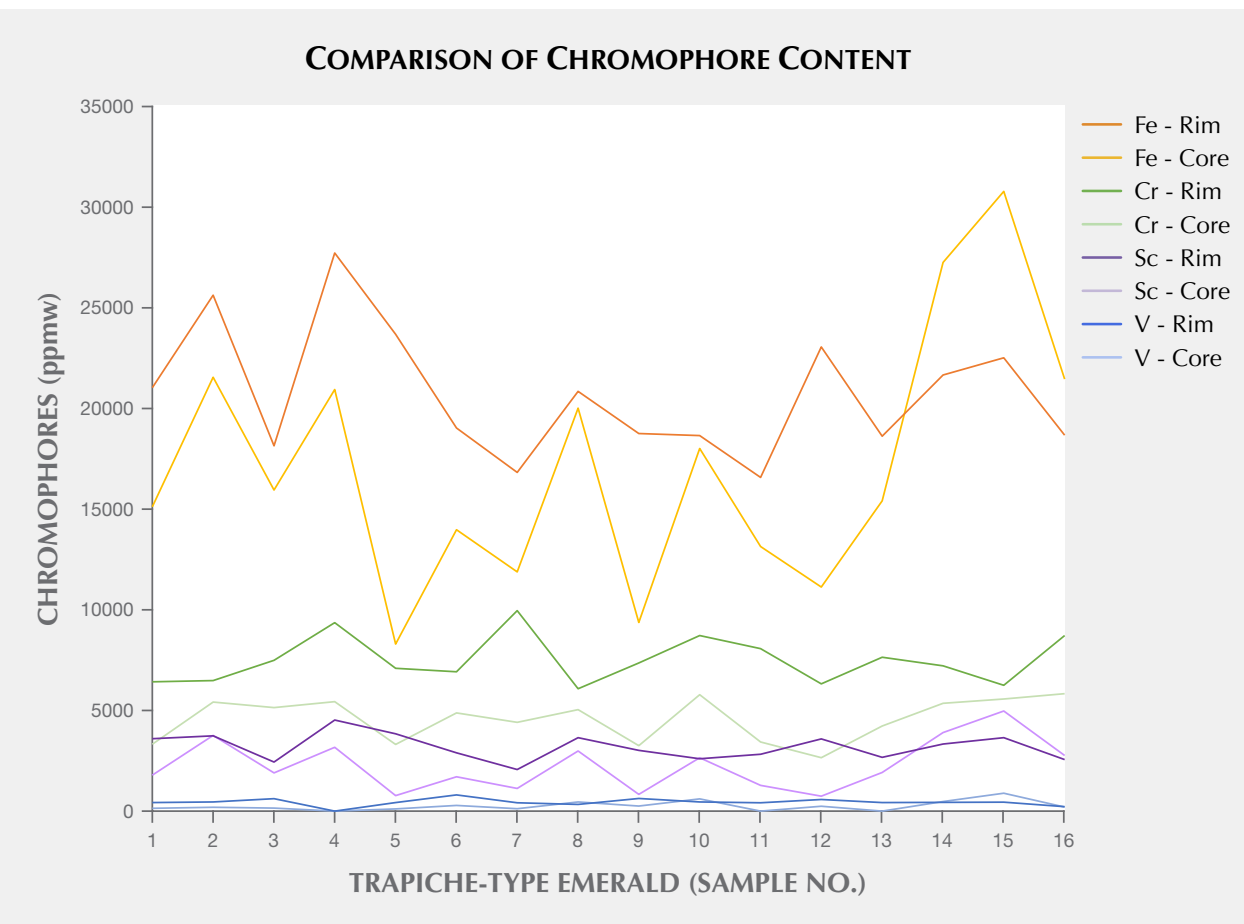

Figure 18. Trapiche-type emeralds from Swat Valley showed the low to high content of Fe, $\mathrm{Cr}, \mathrm{Sc}$, and $\mathrm{V}$ from the core (colorless) to rim (green), except samples 14-16, whose cores were too small.
The infrared spectroscopy in the $3200-2500 \mathrm{~cm}^{-1}$ range is helpful to identify possible fillers used for clarity enhancement. None of the green fillers were seen in any samples, but some of the stones containing a near-colorless filler showed infrared spectra (figure 17, right) typical of cedarwood oil and Araldite 6010, as indicated by absorptions at 3047, 3014, 2962, 2924, and $2869 \mathrm{~cm}^{-1}$ (Johnson et al., 1999).

Main and Trace Element Analysis. Eleven fabricated regular emerald samples were analyzed using LAICP-MS (table 2) and sixteen trapiche-type samples were measured by EDXRF (table 3).

Regular Swat emeralds tended to have high concentrations of $\mathrm{Li}, \mathrm{Na}, \mathrm{Rb}, \mathrm{Cs}, \mathrm{Mg}$, and $\mathrm{Fe}$, as well as Sc. Total alkali ion concentrations ranged from 16850 to 24475 ppmw (avg. 21040 ppmw); Mg contents ranged from 15149 to 226396 ppmw (avg. 34263 ppmw), while Fe ranged from 2533 to 59538 ppmw (avg. 9265 ppmw). Sc ranged from 254 to 1408 ppmw (avg. $633 \mathrm{ppmw}$ ). The concentrations of $\mathrm{Cr}(459-$ 23041 ppmw, avg. $7471 \mathrm{ppmw}$ ) were greater than $\mathrm{V}$ (297-802 ppmw, avg. 565 ppmw), and the $\mathrm{Cr} / \mathrm{V}$ ratio ranged from 0.8 to 42 .

The results of EDXRF from the trapiche-type emeralds showed high contents of Fe (avg. 17801 ppmw), Cr (avg. 5795 ppmw), and Sc (avg. 2367 ppmw). Figure 18 indicated the low-to-high content trend of Fe (14968-20633 ppmw), Cr (4235-7362 ppmw), Sc (1767-2966 ppmw), and V (190-442 ppmw). From the green rim to colorless core, the charts showed a positive correlation between these elements and the green color. However, three samples (14-16) showed an opposite trend of $\mathrm{Fe}, \mathrm{Sc}$, and $\mathrm{V}$, because the colorless core was too small.

\section{DISCUSSION}

Variations in Properties. The RI, SG, pleochroism, and fluorescence of the samples were consistent with the properties of the Swat emeralds studied by Gübelin (1982) and Bowersox and Anwar (1989). Compared with Afghan emeralds $\left(\mathrm{n}_{\mathrm{o}}=1.572-1.580\right.$, $\mathrm{n}_{\mathrm{e}}=1.580-1.590$, and $\mathrm{SG}=2.68-2.74$; Bowersox et al., 1991; Saeseaw et al., 2014), Swat emeralds have higher values of RI and SG, which may be explained by the fact that Swat emeralds have higher alkali metal content (avg. 21040 ppmw) than Afghan emeralds (avg.10780 ppmw; Saeseaw et al., 2014). Meanwhile, trapiche-type emeralds from Swat Valley showed higher RI than regular Swat emeralds, possibly because their Fe content was higher (avg. 17801 ppmw) than that in other Swat emeralds (avg. 9265 ppmw).

Microscopic Inclusions. Swat trapiche-type emeralds are different from Colombian trapiche emeralds in their structural characteristics and chemical composition. The black arms of Colombian trapiche 
TABLE 2. Chemical composition of 11 regular Swat emeralds, obtained by LA-ICP-MS. ${ }^{\text {a }}$

\begin{tabular}{|c|c|c|c|c|c|c|c|c|c|c|c|}
\hline \multirow{2}{*}{$\begin{array}{l}\text { Element } \\
\text { (ppmw) }\end{array}$} & \multicolumn{2}{|l|}{ YE-1 } & \multicolumn{2}{|l|}{ YE-2 } & \multicolumn{2}{|l|}{ YE-3 } & \multicolumn{2}{|l|}{ YE-5 } & \multicolumn{2}{|l|}{ YE-8 } & \multirow{2}{*}{$\begin{array}{c}\text { YE-9 } \\
\text { Range }\end{array}$} \\
\hline & Range & Average & Range & Average & Range & Average & Range & Average & Range & Average & \\
\hline $\mathrm{Li}$ & 465-495 & 480 & $453-472$ & 462 & $363-401$ & 382 & $426-677$ & 559 & $279-416$ & 319 & $261-342$ \\
\hline $\mathrm{Be}$ & 144484-154269 & 149376 & 143110-144562 & 143836 & 143128-153712 & 148420 & 126409-148358 & 136710 & 137721-156481 & 148007 & 134890-140497 \\
\hline B & $10-16$ & 13 & $8-10$ & 9 & $5-7$ & 6 & $0-7$ & 4 & $5-7$ & 6 & $8-9$ \\
\hline $\mathrm{Na}$ & 19924-22394 & 21159 & 19142-19445 & 19294 & 20853-21369 & 21111 & 19752-22291 & 21076 & 19267-20316 & 19909 & 19582-20080 \\
\hline Mg & 23784-27404 & 25594 & 22683-23644 & 23164 & $26187-27782$ & 26985 & 21022-26056 & 23882 & 21362-25091 & 23486 & 25327-75919 \\
\hline $\mathrm{Al}$ & 186416-208015 & 197216 & 63644-190831 & 127237 & 196367-221695 & 209031 & 26056-193631 & 112319 & 174942-200915 & 189729 & 183375-184196 \\
\hline Si & 581535-588087 & 584811 & 600199-606942 & 603571 & 564235-596050 & 580143 & $605682-622151$ & 616073 & 580772-607906 & 593350 & 559408-614869 \\
\hline$P$ & $147-187$ & 167 & 204-223 & 214 & $347-480$ & 414 & 145-186 & 173 & $171-225$ & 204 & 185-210 \\
\hline Sc & 1092-1282 & 1187 & $503-508$ & 506 & 548-639 & 594 & $254-377$ & 309 & 590-1169 & 851 & $390-523$ \\
\hline $\mathrm{Ti}$ & 93-106 & 99 & 139-141 & 140 & $231-300$ & 265 & 94-116 & 104 & 99-505 & 295 & 203-280 \\
\hline V & $564-576$ & 570 & $480-520$ & 500 & 698-703 & 700 & 297-608 & 448 & $641-796$ & 716 & 576-802 \\
\hline $\mathrm{Cr}$ & $580-8831$ & 4706 & $3454-6655$ & 5054 & $1257-3537$ & 2397 & 459-23041 & 8646 & 3248-20353 & 10251 & 2554-2813 \\
\hline Mn & $7-9$ & 8 & 1 & 1 & 3 & 3 & $0-11$ & 5 & $1-3$ & 2 & $1-306$ \\
\hline $\mathrm{Fe}$ & 9809-10190 & 9999 & $4185-4241$ & 4213 & 5559-6891 & 6225 & $3847-5568$ & 4873 & 4385-7787 & 6204 & 7871-18432 \\
\hline Co & 1 & 1 & 1 & 1 & $1-2$ & 1 & 1 & 1 & 1 & 1 & $1-10$ \\
\hline $\mathrm{Zn}$ & $3-5$ & 4 & 4 & 4 & $7-8$ & 8 & $3-6$ & 5 & $2-4$ & 3 & $2-9$ \\
\hline Ga & 6 & 6 & $3-4$ & 4 & $5-6$ & 6 & $5-6$ & 6 & $4-6$ & 5 & $4-5$ \\
\hline $\mathrm{Rb}$ & $10-12$ & 11 & 12 & 12 & $11-18$ & 14 & $9-11$ & 10 & $9-13$ & 11 & 10-11 \\
\hline Cs & $157-161$ & 159 & 120-131 & 125 & 418-793 & 605 & 98-138 & 114 & 128-219 & 182 & 110-196 \\
\hline Th & $0-0.01$ & 0.005 & nd & nd & nd & nd & $0-0.028$ & 0.013 & $0-0.011$ & 0.006 & nd \\
\hline U & nd & nd & nd & nd & $0-0.027$ & 0.014 & $0-0.011$ & 0.003 & nd & nd & $0-0.014$ \\
\hline
\end{tabular}

${ }^{a} \mathrm{Ca}, \mathrm{Ni}, \mathrm{Cu}, \mathrm{Ge}, \mathrm{As}, \mathrm{Sr}, \mathrm{Y}, \mathrm{Zr}, \mathrm{Nb}, \mathrm{Mo}, \mathrm{Cd}, \mathrm{In}, \mathrm{Sn}, \mathrm{Sb}, \mathrm{Ba}, \mathrm{La}, \mathrm{Ce}, \mathrm{Pr}, \mathrm{Nd}, \mathrm{Sm}, \mathrm{Eu}, \mathrm{Gd}, \mathrm{Tb}, \mathrm{Dy}, \mathrm{Ho}, \mathrm{Er}, \mathrm{Tm}, \mathrm{Yb}, \mathrm{Lu}, \mathrm{Hf}, \mathrm{Ta}, \mathrm{W}, \mathrm{Bi}$, and Pb could not be analyzed correctly by this technique. Abbreviations: $n d=$ not detected.

emeralds are composed mainly of carbonaceous material and albite (Ohnenstetter et al., 1998), while the arms of Swat trapiche-type emeralds are a mixture of hematite and graphite. Gao et al. (2019) identified the black arms as magnetite, while the mixture of

TABLE 3. Chemical composition (average) of trapiche-type emeralds from Swat Valley, analyzed by EDXRF.

\begin{tabular}{|c|c|c|c|c|}
\hline $\begin{array}{l}\text { Element } \\
(\text { ppmw) }\end{array}$ & $\mathrm{Fe}$ & $\mathrm{Cr}$ & Sc & V \\
\hline $\begin{array}{l}\text { Core } \\
\text { (colorless) }\end{array}$ & $\begin{array}{c}8288-21529 \\
(14968)\end{array}$ & $\begin{array}{c}2593-5652 \\
(4235)\end{array}$ & $\begin{array}{c}691-3501 \\
(1767)\end{array}$ & $\begin{array}{c}\text { bdl-591 } \\
(190)\end{array}$ \\
\hline $\begin{array}{l}\text { Rim } \\
\text { (green) }\end{array}$ & $\begin{array}{c}16556-27691 \\
(20633)\end{array}$ & $\begin{array}{c}\text { 5939-9729 } \\
(7362)\end{array}$ & $\begin{array}{c}1923-4212 \\
(2966)\end{array}$ & $\begin{array}{c}\text { bdl-782 } \\
(442)\end{array}$ \\
\hline Average & 17801 & 5795 & 2367 & 319 \\
\hline Det. limit & 21 & 4.8 & 20 & 2.1 \\
\hline
\end{tabular}

hematite and graphite was identified in this study. Hematite $\left(\mathrm{Fe}_{2} \mathrm{O}_{3}\right)$ indicates oxidation conditions, while the magnetite $\left(\mathrm{Fe}_{3} \mathrm{O}_{4}\right)$ is formed under reducing conditions. Thus, there is a transformation between magnetite and hematite under different redox conditions.

Swat emeralds appear to have characteristic multiphase inclusions. Descriptions of multi-phase inclusions in Swat emeralds are available in the gemological literature (Gübelin, 1982; Bowersox and Anwar, 1989), but with few details. Three-phase inclusions in Swat emeralds were rather rare. Three-phase inclusions occur in emeralds from Colombia, Panjshir (Afghanistan), Davdar (China), and Kafubu and Musakashi (Zambia). But this is the first time that specific components of three-phase inclusions have been reported in Swat Valley emeralds from Pakistan, which are different from the jagged three-phase inclusions in 


\begin{tabular}{|c|c|c|c|c|c|c|c|c|c|c|}
\hline YE-9 & \multicolumn{2}{|l|}{ YE-11 } & \multicolumn{2}{|l|}{ YE-12 } & \multirow{2}{*}{$\begin{array}{l}\text { YE-13 } \\
\text { Value }\end{array}$} & \multicolumn{2}{|l|}{ YE-14 } & \multicolumn{2}{|l|}{ YE-16 } & \multirow{2}{*}{$\begin{array}{l}\text { Detection } \\
\text { limit } \\
(p p m w)\end{array}$} \\
\hline Average & Range & Average & Range & Average & & Range & Average & Range & Average & \\
\hline 301 & $309-581$ & 445 & $83-95$ & 89 & 478 & $247-614$ & 425 & $315-343$ & 329 & 2.3 \\
\hline 137694 & 111068-121629 & 116349 & 126819-134255 & 130537 & 159847 & 155724-165842 & 160826 & $152503-154254$ & 153378 & 9.8 \\
\hline 8 & $1-6$ & 4 & $10-14$ & 12 & 10 & $8-16$ & 12 & $10-11$ & 11 & 2.9 \\
\hline 19831 & 16370-21636 & 19003 & 23213-23269 & 23241 & 17695 & 19597-21452 & 20338 & 20041-20461 & 20251 & 128 \\
\hline 50623 & $26502-226396$ & 126449 & 27908-28974 & 28441 & 15149 & 15786-28550 & 20136 & $26572-35393$ & 30982 & 24 \\
\hline 183786 & 122485-211335 & 166910 & $63644-67908$ & 65776 & 160092 & 149723-162515 & 156364 & 192267-193961 & 193114 & 18 \\
\hline 587139 & $444875-594926$ & 519901 & $603075-603763$ & 603419 & 636495 & $608483-624603$ & 616343 & $580977-582667$ & 581822 & 1150 \\
\hline 198 & $307-485$ & 396 & $196-197$ & 197 & 143 & $72-171$ & 145 & $191-193$ & 192 & 60 \\
\hline 456 & $556-583$ & 570 & $1325-1408$ & 1366 & 340 & $327-464$ & 381 & $553-576$ & 564 & 1.7 \\
\hline 242 & $123-150$ & 137 & $107-149$ & 128 & 93 & $86-124$ & 102 & $148-174$ & 161 & 24 \\
\hline 689 & $331-342$ & 337 & $324-378$ & 351 & 509 & $549-604$ & 576 & $649-700$ & 675 & 0.9 \\
\hline 2683 & 8667-9029 & 8848 & 5029-9212 & 7121 & 3415 & 8329-18982 & 13243 & $1862-8633$ & 5247 & 2.3 \\
\hline 153 & $4-1187$ & 595 & $23-34$ & 29 & 2 & $3-10$ & 5 & $5-67$ & 36 & 1.8 \\
\hline 13151 & $7623-59538$ & 33580 & 14491-19188 & 16840 & 2757 & $2533-5717$ & 3429 & $7672-10444$ & 9058 & 230 \\
\hline 5 & $1-29$ & 15 & $1-3$ & 2 & 1 & $1-6$ & 2 & $1-2$ & 2 & 1.0 \\
\hline 5 & $5-27$ & 16 & 14 & 14 & 3 & $4-10$ & 7 & $5-14$ & 10 & 1.9 \\
\hline 4 & $5-6$ & 5 & 13 & 13 & 3 & $3-8$ & 5 & $3-4$ & 4 & 0.4 \\
\hline 11 & 12 & 12 & $40-71$ & 55 & 6 & $9-12$ & 11 & 12 & 12 & 1.1 \\
\hline 153 & $144-159$ & 151 & 868-1096 & 982 & 94 & $67-103$ & 85 & 138-141 & 139 & 0.5 \\
\hline nd & $0-0.029$ & 0.014 & nd & nd & nd & nd & nd & $0-0.003$ & 0.001 & 0.01 \\
\hline 0.007 & nd & nd & nd & nd & nd & nd & nd & nd & nd & 0.001 \\
\hline
\end{tabular}

Colombian emeralds. The outlines of the cavities of the three-phase inclusions are typically hexagonal and regular, suggesting that they were formed at the same time as the emerald host. The solid phase is magnesite, unlike three-phase inclusions from any other source (Saeseaw et al., 2014). Furthermore, the mixed gas of three-phase inclusions $\left(\mathrm{CO}_{2}+\mathrm{N}_{2}\right)$ in trapiche-type emeralds is different from that in regular Swat emeralds $\left(\mathrm{CO}_{2}+\mathrm{N}_{2}+\mathrm{CH}_{4}\right)$, which shows some different conditions of formation in trapiche-type emeralds. The solid inclusions hematite, magnetite, rutile, graphite, and siderite identified in this study are new for emeralds from Swat Valley.

Trace-Element Variations. Several published studies represent an early attempt to use trace elements for provenance purposes (Saeseaw et al., 2014, 2019; Carlo et al., 2018), but the data for Swat emeralds is scarce. In this study, 27 spots on 11 regular Swat emeralds were analyzed via LA-ICP-MS. Logarithm plots of trace elements were applied to detect possible correlations when distinguishing geographic origin, so adding LA-ICP-MS data from other main emerald deposits in the world is necessary, such as Colombia, Kafubu from Zambia, Brazil (Zwaan et al., 2012), Panjshir from Afghanistan, Swat from Pakistan (Carlo et al., 2018), Khaltaro from Pakistan (Laurs et al., 1996), Russia (Saeseaw et al., 2019; Carlo et al., 2018; Karampelas et al., 2019; all averages), Ethiopia (Saeseaw et al., 2019; Carlo et al., 2018; Karampelas et al., 2019; all averages), Egypt (Carlo et al., 2018), India (Carlo et al., 2018), and Malipo from China (Zheng et al., 2019). The inclusions of Ethiopian and Russian emeralds (Saeseaw et al., 2019) are very similar to those in Swat emeralds. But the high Cr (avg. 7471 ppmw), high V (avg. 565 ppmw), and high Fe (avg. 


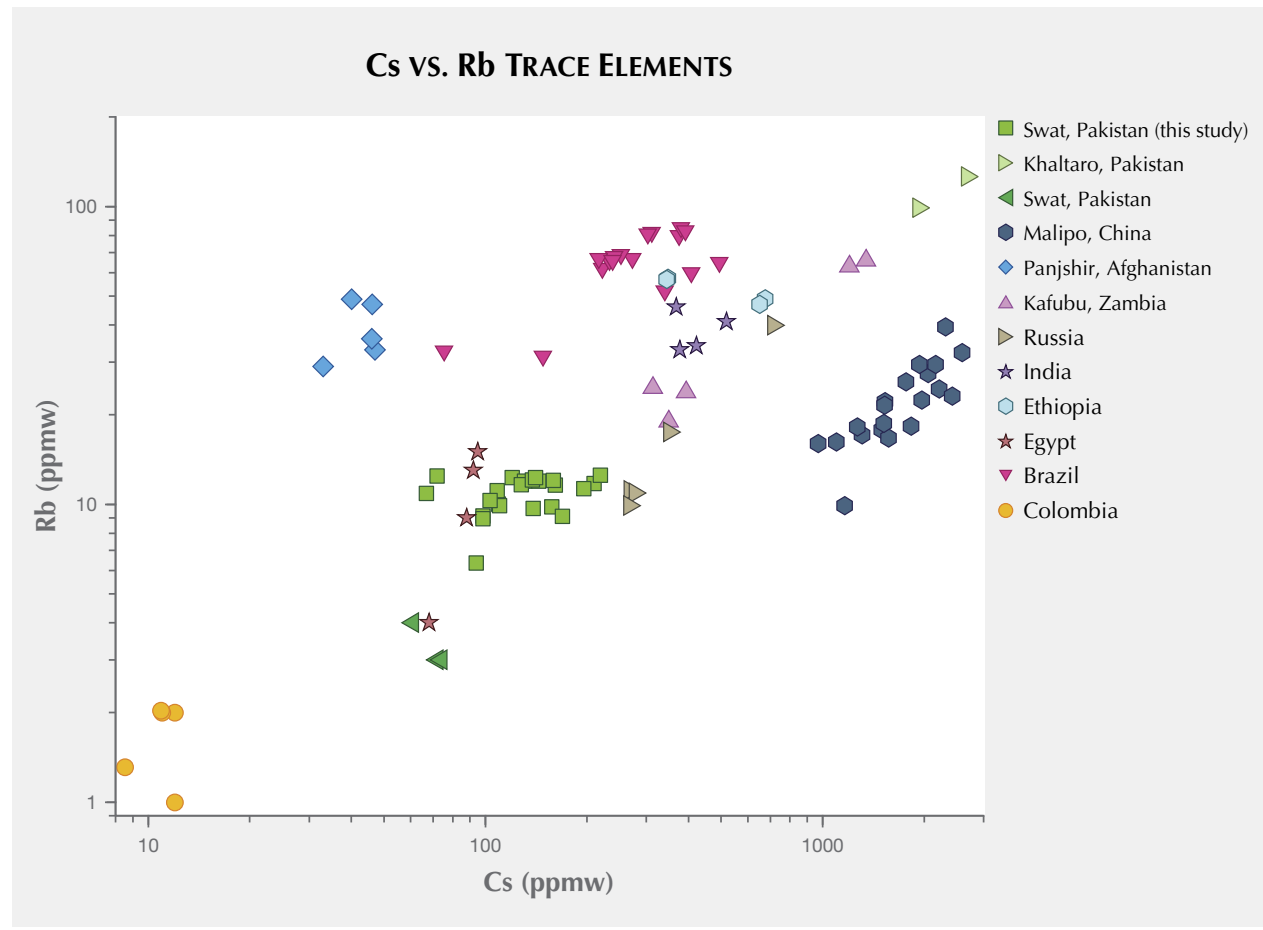

Figure 19. A log-log plot of $C s$ versus $R b$ concentrations from LA-ICPMS analyses clearly shows a positive correlation in emeralds from Swat and other localities. Other sources are from Saeseaw et al. (2019) (average), Carlo et al. (2018), Karampelas et al. (2019) (average), Laurs et al. (1996), Zwaan et al. (2012), and Zheng et al. (2019).

9265 ppmw) content can clearly separate the Swat The plots of Cs versus $\mathrm{Rb}$ and Li versus Cs showed a emeralds from Ethiopian (avg. 3655 ppmw Cr; avg. 112.70 ppmw V; avg. 4867 ppmw Fe) and Russian (avg. 905.27 ppmw Cr; avg. 80.64 ppmw V; avg. positive correlation (figure 19 and 20), but there is some overlap for emeralds from Swat Valley, Russia, 1600.67 ppmw Fe) emeralds (Karampelas et al., 2019).

Ethiopia, India, Egypt, and Zambia. The plot of Li versus Sc proved useful in separating Swat Valley from

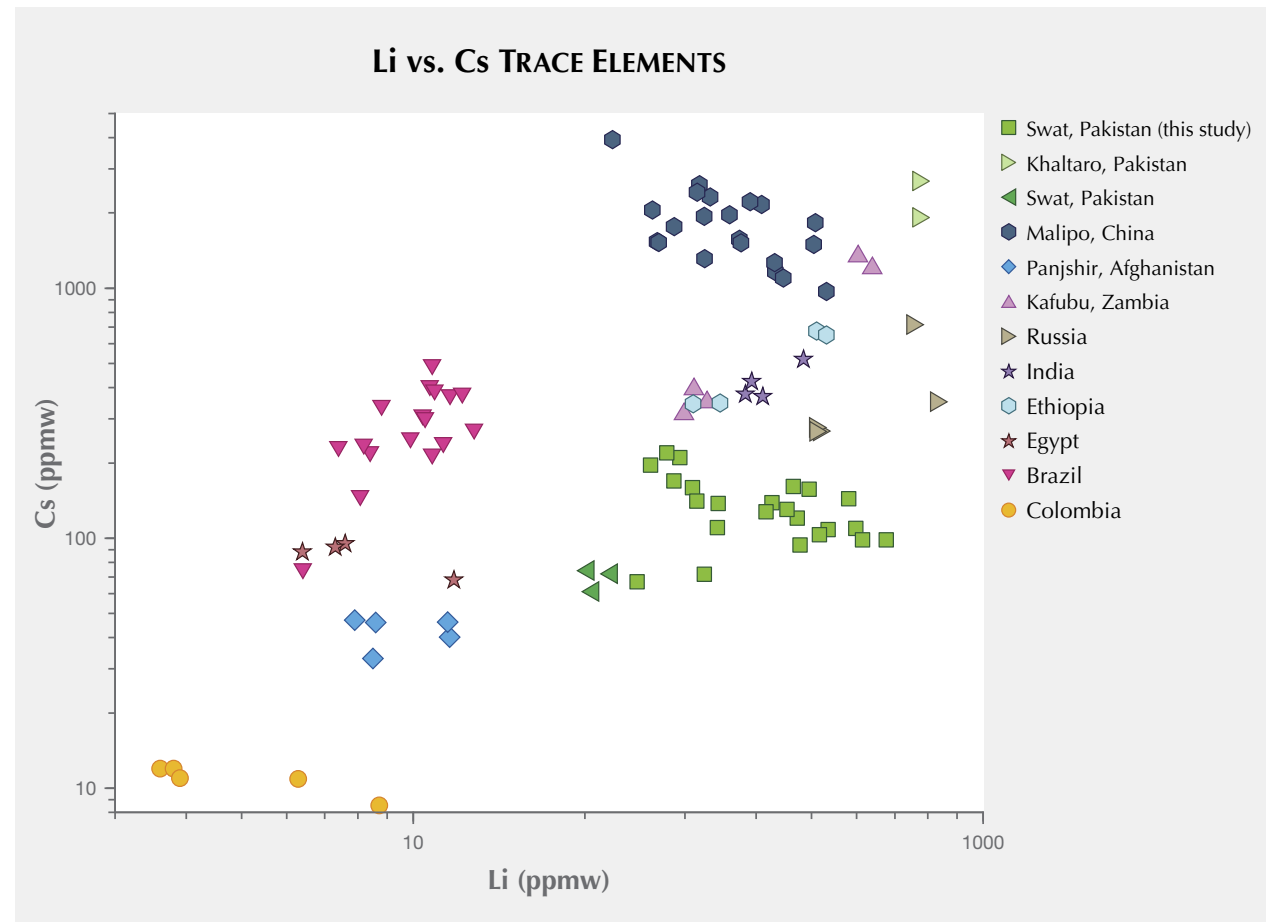

Figure 20. A log-log plot of Li versus Cs concentrations from LA-ICPMS analyses clearly shows a positive correlation in Swat and other localities emeralds. Sources of data are the same as in figure 19. 
most occurrences (figure 21), but there is a small overlap for emeralds from Pakistan, Egypt, and Afghanistan. It also showed Swat emeralds contained high $\mathrm{Cs}$ and $\mathrm{Li}$, which can be used to distinguish among Swat, Egyptian, and Afghani emeralds. Particularly, the average of $\mathrm{Mg}$ concentrations (34263 ppmw) in Swat emeralds is the highest among worldwide sources.

\section{CONCLUSIONS}

Overall, the gemological properties of Swat samples are distinct and can be used in origin determination. Relatively higher values of RI and SG are related to rich alkali metal contents in Swat emeralds. The main chromophores in Swat emeralds are $\mathrm{Cr}^{3+}, \mathrm{V}^{3+}$, $\mathrm{Fe}^{3+}$, and $\mathrm{Fe}^{2+}$, of which $\mathrm{Cr}^{3+}$ is the most important cause for green color (figure 22). But the spectrum of the trapiche-type emerald illustrates the strong $\mathrm{Fe}^{3+}$ band at $370 \mathrm{~nm}$, different from regular Swat emeralds.

This is the first time that the gemological and geochemical details of trapiche-type emeralds from Swat Valley have been published. Compared with regular Swat emeralds, trapiche-type emeralds show higher RI because of higher Fe content. There are four parts: one or two colorless beryl cores, a light green hexagonal growth zone area, a green rim, and six (or two sets of six) black hematite and graphite arms. The

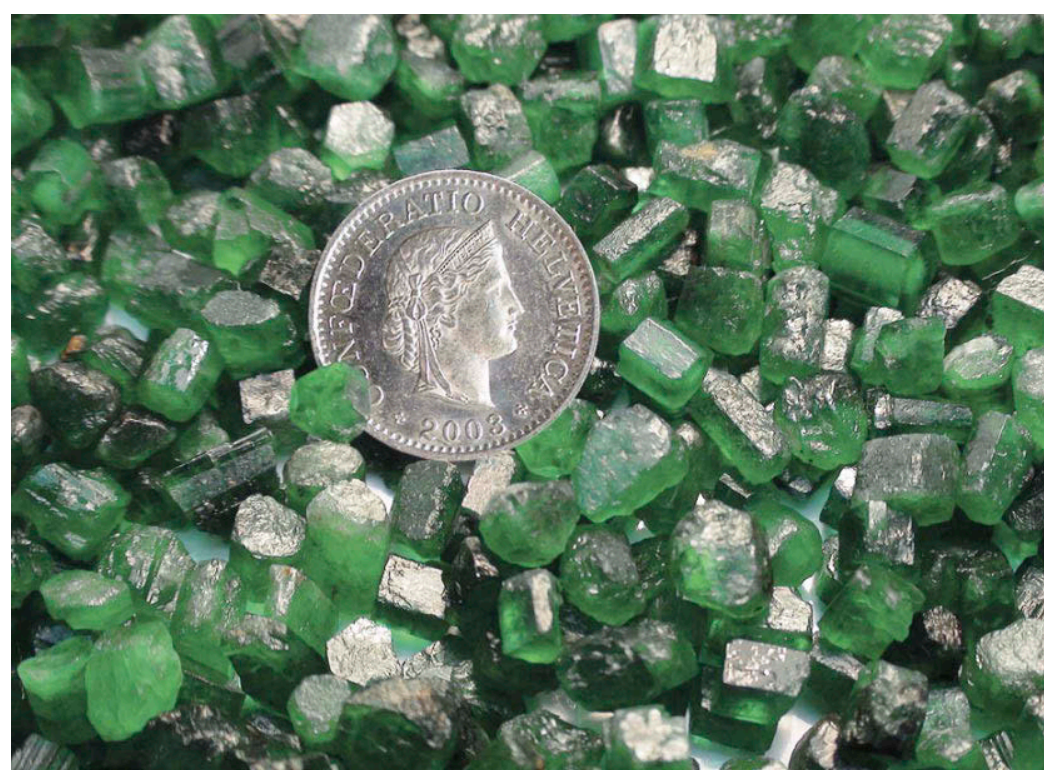

Figure 22. Emerald crystals from the Mingora mine in Swat Valley typically show good color saturation. Photo by Andrew Lucas/GIA.

chemical contents of $\mathrm{Fe}, \mathrm{Cr}$, Sc, and $\mathrm{V}$ in trapiche-type emeralds have a trend from low to high going from the colorless core to the green rim.

Some typical inclusions are present in Swat emeralds. First, one solid magnesite, one $\mathrm{CO}_{2}+\mathrm{N}_{2}$ bubble and liquid phase were identified in three-phase inclu-

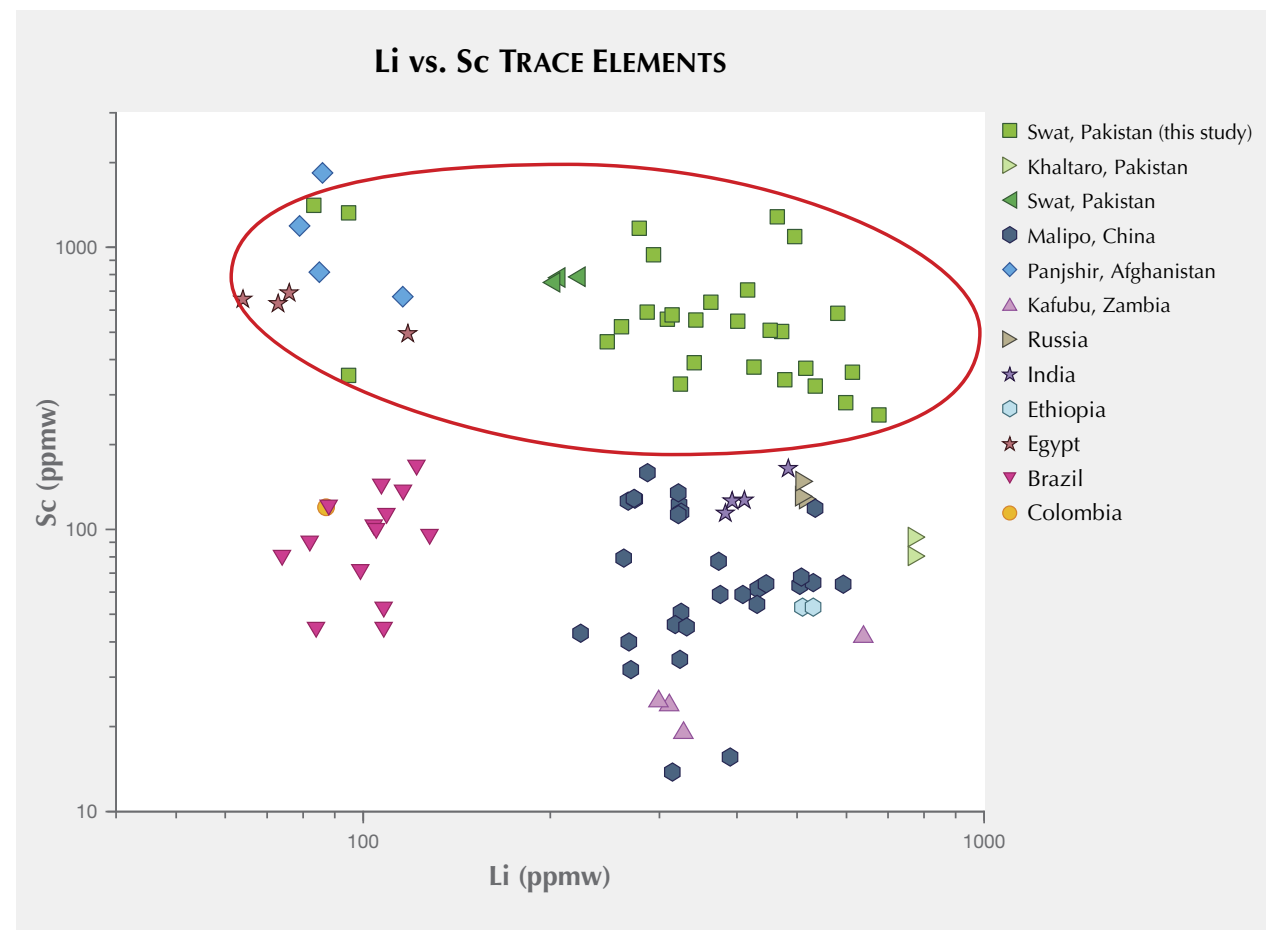

Figure 21. A log-log plot of Li versus Sc concentrations from $L A$ ICP-MS analyses is useful in separating between Swat emeralds and those from other occurrences. Sources of data are the same as in figure 19. 
sions. Second, the gaseous mixture $\left(\mathrm{CO}_{2}+\mathrm{N}_{2}+\mathrm{CH}_{4}\right.$ or $\mathrm{CO}_{2}+\mathrm{N}_{2}$ ) in necked-down, elongated, or irregular two-phase inclusions is not identical to other origins. Third, the solid mineral inclusions in regular Swat emeralds typically included magnesite, dolomite, quartz, fluorite, siderite, talc, muscovite, rutile, hematite, magnetite, and graphite. In the trapichetype emeralds, hematite, graphite, and two-phase inclusions were commonly observed.

The infrared spectrum illustrates the typical features that the absorption of the type $\mathrm{II}_{2} \mathrm{O} / 7095$ and $5267 \mathrm{~cm}^{-1}$ ) is stronger than that of the peak of type $\mathrm{I}_{2} \mathrm{O}\left(6843 \mathrm{~cm}^{-1}\right)$. The significant peak at 2356 $\mathrm{cm}^{-1}$ corresponds to $\mathrm{CO}_{2}$. Some of the samples are filled with mixtures of cedarwood oil and Araldite 6010.

Trace-element chemistry can provide additional valuable tools for origin determination. The logarithmic plots of trace element data from LA-ICP-MS analyses such as $\mathrm{Li}$ versus $\mathrm{Sc}$, Cs versus $\mathrm{Rb}$, and $\mathrm{Li}$ versus Cs are distinct for this locality. These emeralds contain relatively high chromium (avg. 7471 ppmw), alkali metal (avg. 21040 ppmw), magnesium (avg. $34263 \mathrm{ppmw}$ ) and iron (avg. $9265 \mathrm{ppmw}$ ), as well as scandium (avg. $633 \mathrm{ppmw}$ ). Based on the identification criteria discussed above, especially microscopic and chemical analysis, separating Swat emeralds from other sources is possible.

\section{ABOUT THE AUTHORS}

Hongshu Guo, Yuyu Zheng, and Zhulin Sun are obtaining master's degrees in gemology, and Dr. Xiaoyan Yu (yuxy@cugb.edu.cn, corresponding author) is director of the gemology teaching and research group and a professor of gemology and mineralogy, at the School of Gemmology, China University of Geosciences in Beijing. Dr. Ng is the founder of the Centre for Gemmological Research in Hong Kong.

\section{ACKNOWLEDGMENTS}

The authors would like to thank Rujie Wang, Hong Chen, Fei Liu, Darwin Daniel Fortaleché, and Cloud Walker Jewel, Inc. for providing samples and valuable information. We also express our gratitude to Zhechen Li for Raman testing support. We sincerely thank every reviewer for useful comments and suggestions. This research was supported by the Fundamental Research Funds for the Central Universities (grant number 53200759978) and China Geological Survey Project "Geology of Mineral Resources in China" (grant number DD20190379-88) to Prof. Xiaoyan Yu.

\section{REFERENCES}

Arif M., Fallick A.E., Moon C.J. (1996) The genesis of emeralds and their host rocks from Swat, northwestern Pakistan: A stable-isotope investigation. Mineralium Deposita, Vol. 31, No. 4, pp. 255-268, http://dx.doi.org/10.1007/BF02280790

Arif M., Henry D.J., Moon C.J. (2011) Host rock characteristics and source of chromium and beryllium for emerald mineralization in the ophiolitic rocks of the Indus Suture Zone in Swat, NW Pakistan. Ore Geology Reviews, Vol. 39, No. 1-2, pp. 120, http://dx.doi.org/10.1016/j.oregeorev.2010.11.006

Bowersox G.W., Anwar J. (1989) The Gujar Killi emerald deposit, Northwest Frontier Province, Pakistan. Ge G, Vol. 25, No. 1, pp. 16-24, http://dx.doi.org/10.5741/GEMS.25.1.16

Bowersox G.W., Snee L.W., Foord E.E., Seal II R.R. (1991) Emeralds of the Panjshir Valley, Afghanistan. $G \uplus G$, Vol. 27, No. 1, pp. 26-39, http://dx.doi.org/10.5741/GEMS.27.1.26

Carlo A., Conte A.M., Medeghini L., Ottolini L., De Vito C. (2018) Major and trace element geochemistry of emerald from several deposits: Implications for genetic models and classification schemes. Ore Geology Reviews, Vol. 94, pp. 351-366, http://dx.doi.org/10.1016/j.oregeorev.2018.02.001

Dilles J.H., Snee L.W., Laurs B.M. (1994) Geology, Ar-Ar age and stable isotopes geochemistry of suture-related emerald mineralization, Swat, Pakistan, Himalayas. In Proceedings of the Geological Society of America, Annual Meeting, Seattle, Washington. Abstracts. Vol. 26, pp. A-311.

Gao Y., Sun X., Shan M. (2019) Gem News International: Trapiche emerald from Swat Valley, Pakistan. GÆG, Vol. 55, No. 3, pp.
$441-442$.

Giuliani G., Groat L.A., Marshall D., Fallick A.E. (2019) Emerald deposits: A review and enhanced classification. Minerals, Vol. 9, No. 2, pp. 105-168, http://dx.doi.org/10.3390/min9020105

Groat L.A., Giuliani G., Marshall D.D., Turner D.B. (2008) Emerald deposits and occurrences: A review. Ore Geology Reviews, Vol. 34, No. 1-2, pp. 87-112, http://dx.doi.org/10.1016/j.oregeorev.2007.09.003

Gübelin E.J. (1982) Gemstones of Pakistan: Emerald, ruby, and spinel. GÆG, Vol. 18, No. 3, pp. 123-139, http://dx.doi.org/ 10.5741/GEMS.18.3.123

Jamal-ud-Din (2014) The neglected emerald mines of Swat. Dawn, August 3, https://www.dawn.com/news/1122968.

Johnson M.L., Elen S., Muhlmeister S. (1999) On the identification of various emerald filling substances. $G \uplus G$, Vol. 35, No. 2, pp. 82-107, http://dx.doi.org/10.5741/GEMS.35.2.82.

Karampelas S., Al-Shaybani B., Mohamed F., Sangsawong S., AlAlawi A. (2019) Emeralds from the most important occurrences: Chemical and spectroscopic data. Minerals, Vol. 9, No. 9 , p. 561, http://dx.doi.org/10.3390/min9090561

Kazmi A.H., Lawrence R.D., Anwar J., Snee L.W., Hussain S.S. (1986) Mingora emerald deposits (Pakistan): suture associated gem mineralization. Economic Geology, Vol. 81, No. 8, pp. 2022-2028.

Khan B. (2018) Emerald occurrences in Pakistan. InColor, No. 40, pp. $80-84$.

Laurs B.M., Dilles J.H., Snee L.W. (1996) Emerald mineralization and metasomatism of amphibolite, Khaltaro granitic pegmatite 
- hydrothermal vein system, Haramosh Mountains, northern Pakistan. Canadian Mineralogist, Vol. 34, No. 6, pp. 1253 1286.

Lawrence R.D., Kazmi A.H., Snee L.W. (1989) Geological setting of the emerald deposits. In A.H. Kazmi and L.W. Snee, Eds., Emeralds of Pakistan. Van Nostrand Reinhold, New York, pp. 13-38.

Li C., Zhou L., Zhao Z., Zhiyuan Z., Zhao H., Li X., Qu W. (2018) In-situ $\mathrm{Sr}$ isotopic measurement of scheelite using fs-LA-MCICPMS. Journal of Asian Earth Sciences, Vol. 160, pp. 38-47, http://dx.doi.org/10.1016/j.jseaes.2018.03.025

Liu Y., Hu Z., Gao S., Günther D., Xu J., Gao C., Chen H. (2008) In situ analysis of major and trace elements of anhydrous minerals by LA-ICP-MS without applying an internal standard. Chemical Geology, Vol. 257, No. 1-2, pp. 34-43, http://dx.doi.org/10.1016/j.chemgeo.2008.08.004

Makki M., Ali S.H. (2019) Gemstone supply chains and development in Pakistan: Analyzing the post-Taliban emerald economy in the Swat Valley. Geoforum, Vol. 100, pp. 166-175, http://dx.doi.org/10.1016/i.geoforum.2019.01.005.

Ohnenstetter D., Giuliani G., Bustos O. (1998) Emeraudes trapiches colombiennes. In L'émeraude. Connaissances actuelles et prospective. Association Française de Gemmologie, pp. 119-124 (in French).

Rehman H.U, Seno T., Yamamoto H., Khan T. (2011) Timing of collision of the Kohistan-Ladakh Arc with India and Asia: Debate. Island Arc, Vol. 20, No. 3, pp. 308-328, http://dx.doi.org/10.1111/j.1440-1738.2011.00774.x
Saeseaw S., Pardieu V., Sangsawong S. (2014) Three-phase inclusions in emerald and their impact on origin determination. $G \uplus G$, Vol 50, No. 2, pp. 114-133, http://dx.doi.org/10.5741/GEMS.50.2.114

Saeseaw S., Renfro N.D., Palke A.C., Sun Z., McClure S.F. (2019) Geographic origin determination of emerald. $G \uplus G$, Vol. 55, No. 4, pp. 614-646, http://dx.doi.org/10.5741/GEMS.55.4.614

Schmetzer K. (2020) Gem News International: Trapiche-type emeralds from Pakistan. $G \uplus G$, Vol. 56, No. 3, p. 438

Schmetzer K., Berdesinski W., Bank H. (1974) Über die Mineralart Beryll, ihre Farben und Absorptionsspektren. Zeitschrift der Deutschen Gemmologischen Gesellschaft, Vol. 23, No. 1, pp. 5-39 (in German).

Wood D.L., Nassau K. (1968) The characterization of beryl and emerald by visible and infrared absorption spectroscopy. American Mineralogist, Vol. 53, No. 5-6, pp. 777-800.

Xu Z., Dilek Y., Yang J., Liang F., Liu F., Ba D., Cai Z., Li G., Dong H., Ji S. (2015) Crustal structure of the Indus-Tsangpo suture zone and its ophiolites in southern Tibet. Gondwana Research, Vol. 27, No. 2, pp. 507-524, http://dx.doi.org/10.1016/j.gr.2014.08.001

Zheng Y., Yu X., Guo H. (2019) Major and trace element geochemistry of Dayakou vanadium-dominant emerald from Malipo (Yunnan, China): Genetic model and geographic origin determination. Minerals, Vol. 9, No. 12, pp. 777-807, http://dx.doi.org/10.3390/min9120777

Zwaan J.C., Jacob D.E., Häger T., Cavalcanti Neto M.T.O., Kanis J. (2012) Emeralds from the Fazenda Bonfim region, Rio Grande do Norte, Brazil. Ge G, Vol. 48, No. 1, pp. 2-17, http://dx.doi.org/10.5741/GEMS.48.1.2

\section{For online access to all issues of GeMs \& GEMOLOGY from 1934 to the present, visit:}

